\title{
Alloys for Aeronautic Applications: State of the Art and Perspectives
}

\author{
Antonio Gloria ${ }^{1}$, Roberto Montanari ${ }^{2, *}$, Maria Richetta ${ }^{2}$ and Alessandra Varone ${ }^{2}$ \\ 1 Institute of Polymers, Composites and Biomaterials, National Research Council of Italy, V.le J.F. Kennedy \\ 54-Mostra d'Oltremare Pad. 20, 80125 Naples, Italy; angloria@unina.it \\ 2 Department of Industrial Engineering, University of Rome “Tor Vergata”, 00133 Rome, Italy; \\ richetta@uniroma2.it (M.R.); alessandra.varone@uniroma2.it (A.V.) \\ * Correspondence: roberto.montanari@uniroma2.it; Tel.: +39-06-7259-7182
}

Received: 16 May 2019; Accepted: 4 June 2019; Published: 6 June 2019

\begin{abstract}
In recent years, a great effort has been devoted to developing a new generation of materials for aeronautic applications. The driving force behind this effort is the reduction of costs, by extending the service life of aircraft parts (structural and engine components) and increasing fuel efficiency, load capacity and flight range. The present paper examines the most important classes of metallic materials including $\mathrm{Al}$ alloys, Ti alloys, $\mathrm{Mg}$ alloys, steels, Ni superalloys and metal matrix composites $(\mathrm{MMC})$, with the scope to provide an overview of recent advancements and to highlight current problems and perspectives related to metals for aeronautics.
\end{abstract}

Keywords: alloys; aeronautic applications; mechanical properties; corrosion resistance

\section{Introduction}

The strong competition in the industrial aeronautic sector pushes towards the production of aircrafts with reduced operating costs, namely, extended service life, better fuel efficiency, increased payload and flight range. From this perspective, the development of new materials and/or materials with improved characteristics is one of the key factors; the principal targets are weight reduction and service life extension of aircraft components and structures [1]. In addition, to reduce the weight, advanced materials should guarantee improved fatigue and wear behavior, damage tolerance and corrosion resistance [2-4].

In the last decade, a lot of research work has been devoted to materials for aeronautic applications and relevant results have been achieved in preparing structural and engine metal alloys with optimized properties.

The choice of the material depends on the type of component, owing to specific stress conditions, geometric limits, environment, production and maintenance. Table 1 reports the typical load conditions of structural sections of a transport aircraft and the specific engineering property requirements, such as elastic modulus, compressive yield strength, tensile strength, damage tolerance (fatigue, fatigue crack growth, fracture toughness) and corrosion resistance.

This work describes the state of the art and perspectives on aeronautic structural and engine materials.

Structural materials must bear the static weight of the aircraft and the additional loads related to taxing, take-off, landing, manoeuvres, turbulence etc. They should have relatively low densities for weight reduction and adequate mechanical properties for the specific application. Another important requirement is the damage tolerance to withstand extreme conditions of temperature, humidity and ultraviolet radiation [5]. 
Figure 1 shows a transport aircraft (Boeing 747), and Table 1 lists the typical load conditions together with the required engineering properties for its main structural sections.

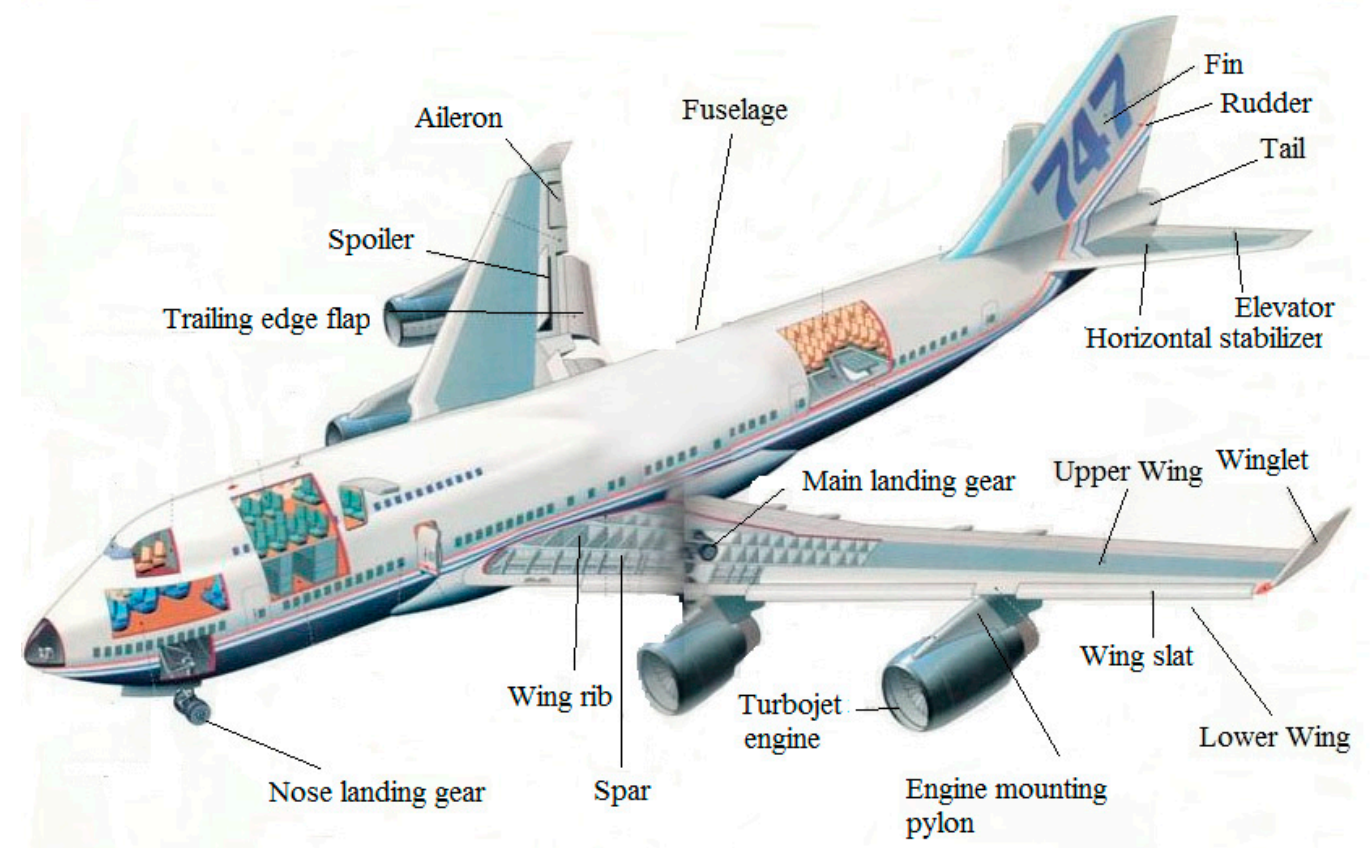

Figure 1. The transport aircraft (Boeing 747) and its main structural sections.

Table 1. Typical load conditions and required engineering properties for the main structural sections in an aircraft. Elastic modulus (E); compressive yield strength (CYS); tensile strength (YS); damage tolerance (DT); corrosion resistance (CR).

\begin{tabular}{cccc}
\hline Aircraft Sections & Section Parts & Load Condition & Engineering Properties \\
\hline \multirow{3}{*}{ Fuselage/Pressure cabin } & Lower skin & Compression & CYS, E, CR \\
\cline { 2 - 4 } & Upper skin & Tension & DT, YS \\
\cline { 2 - 4 } & Stringers/Frame & & CYS, E, DT, YS \\
\cline { 2 - 4 } & Seat/cargo tracks & YS, CR \\
\hline \multirow{2}{*}{ Upper wing } & Floor beams & E, YS \\
\cline { 2 - 4 } & Skin/Stringers & & High CYS, E, DT \\
\hline Lower wing & Spars & Tension & CYS, E, CR \\
\hline \multirow{2}{*}{ Horizontal stabilizers } & Skin/Stringers/Spars & High DT, YS \\
\cline { 2 - 4 } & Lower & Compression & CYS, E, DT \\
\hline
\end{tabular}

As shown in Figure 2, engines consist of cold (fan, compressor and casing) and hot (combustion chamber and turbine) sections. The material choice depends on the working temperature. The components of cold sections require materials with high specific strength and corrosion resistance. $\mathrm{Ti}$ and $\mathrm{Al}$ alloys are very good for these applications. For instance, the working temperature of the compressor is in the range of $500-600{ }^{\circ} \mathrm{C}$, and the Ti-6Al-2Sn-4Zr-6Mo alloy (YS $=640 \mathrm{MPa}$ at $450{ }^{\circ} \mathrm{C}$; excellent corrosion resistance) is the most commonly used material.

For the hot sections, materials with good creep resistance, mechanical properties at high temperature and high-temperature corrosion resistance are required, and Ni-base superalloys are the optimal choice. 


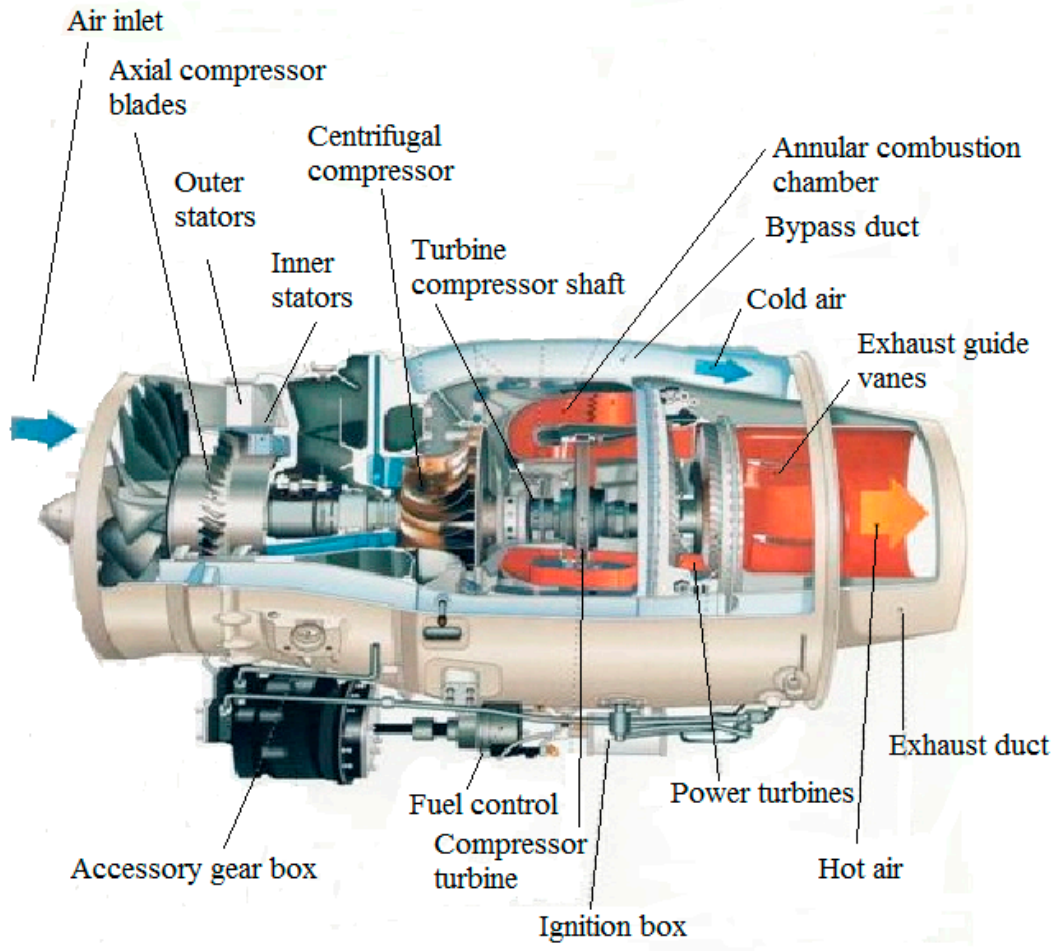

Figure 2. Schematic view of a turbofan engine.

\section{Aluminum Alloys}

For many years, $\mathrm{Al}$ alloys have been the most widely used materials in aeronautics; however, the scenario is rapidly evolving, as shown by Table 2, which reports the approximate primary structure materials used by weight in Boeing aircrafts. From these data, it is evident that an increasing role is being played by composites [4].

Table 2. Materials used in Boeing aircrafts (weight \%). The term "Others" refers to materials present in very small amounts, including metal alloys $(\mathrm{Mg}$, refractory metals etc.) and carbon.

\begin{tabular}{cccccc}
\hline Boeing Series & Al Alloys & Ti Alloys & Steels & Composites & Others \\
\hline 747 & 81 & 4 & 13 & 1 & 1 \\
757 & 78 & 6 & 12 & 3 & 1 \\
767 & 80 & 2 & 14 & 3 & 1 \\
777 & 70 & 7 & 11 & 11 & 1 \\
787 & 20 & 15 & 10 & 50 & 5 \\
\hline
\end{tabular}

Anyway, in spite of the rising use of composites, $\mathrm{Al}$ alloys still remain materials of fundamental importance for structural applications owing to their light weight, workability and relative low cost, and relevant improvements have been achieved especially for 2XXX, 7XXX and Al-Li alloys. In general, the $2 X X X$ series alloys are used for fatigue critical applications because they are highly damage tolerant; those of the 7000 series are used where strength is the main requirement, while Al-Li alloys are chosen for components which need high stiffness and very low density.

\section{1. $2 X X X$ Series- $(A l-C u)$}

Where damage tolerance is the primary criterion for structural applications, $\mathrm{Al}-\mathrm{Cu}$ alloys ( $2 X X X$ series) are the most used materials. The alloys of the $2 X X X$ series containing Mg have: (i) higher strength due to the precipitation of the $\mathrm{Al}_{2} \mathrm{Cu}$ and $\mathrm{Al}_{2} \mathrm{CuMg}$ phases; (ii) better resistance to 
damage; (iii) better resistance to fatigue crack growth compared to other series of $\mathrm{Al}$ alloys. For these reasons, 2024-T3 is still one of the most widely used alloys in fuselage construction.

Nevertheless, it is worth noting that the $2 \mathrm{XXX}$ series alloys present some drawbacks: (i) the relatively low YS limits their use in components subject to very high stresses; (ii) the phase $\mathrm{Al}_{2} \mathrm{CuMg}$ can act as an anodic site, drastically reducing the corrosion resistance.

Improvements can be achieved by a suitable tailoring of the composition and a strict control of the impurities. In particular, the addition of some alloying elements such as $\mathrm{Sn}, \mathrm{In}, \mathrm{Cd}$ and $\mathrm{Ag}$ can be useful to refine the microstructure, thus improving the mechanical properties, e.g., an increase in hardness, YS and UTS was found by increasing Sn content up to $0.06 \mathrm{wt} \%$ [6].

A further increase in mechanical properties can be obtained by controlling the level of impurities such as Fe and Si. For example, the alloy 2024-T39, which has a content of Fe+Si equal to $0.22 \mathrm{wt} \%$, much lower than that of the 2024 alloy $(0.50 \mathrm{wt} \%)$, exhibits an ultimate tensile strength (UTS) value of $476 \mathrm{MPa}$, while that of a conventional 2024 alloy is $428 \mathrm{MPa}$.

\section{2. $7 X X X$ Series- $(A l-Z n)$}

Among all metals, $\mathrm{Zn}$ has the highest solubility in $\mathrm{Al}$, and the strength results improved by increasing $\mathrm{Zn}$ content. The $7 \mathrm{XXX}$ series alloys represent the strongest $\mathrm{Al}$ alloys, and are used for high-stressed aeronautic components; for example, upper wing skins, stringers and stabilizers are manufactured with the alloy $7075(\mathrm{YS}=510 \mathrm{MPa})$.

$\mathrm{Mg}$ and $\mathrm{Cu}$ are often used in combination with $\mathrm{Zn}$ to form $\mathrm{MgZn}_{2}, \mathrm{Al}_{2} \mathrm{CuMg}$ and $\mathrm{AlCuMgZn}$ precipitates which lead to a significant strengthening of the alloy [7].

However, there are also some drawbacks to the 7XXX series. Specifically, the low fracture toughness, damage tolerance and corrosion resistance limit the use of the 7075 alloy in the aeronautic industry. Anyway, the composition can be varied to improve their properties.

The optimal properties of the 7XXX series are obtained when the $\mathrm{Zn} / \mathrm{Mg}$ and $\mathrm{Zn} / \mathrm{Cu}$ ratios are approximately equal to 3 and 4, respectively. Alloy 7085 is a possible alternative to 7075 for aerospace applications due to its excellent mechanical properties ( $\mathrm{YS}=504 \mathrm{MPa}$, elongation $=14 \%$ ) and better damage tolerance (44 MPa $\mathrm{m}^{1 / 2}$ ). $\mathrm{Zr}$ and $\mathrm{Mn}$ can be added up to $1 \%$ as they refine the grain and consequently improve the mechanical properties.

Another important issue related to the specific applications of 7XXX series alloys is the fatigue behavior, and a lot of work has been devoted to the matter, taking into consideration different parameters [8-13].

Material discontinuities are often associated with crack nucleation. On a micro-scale, roughness and precipitate particles may act as preferred nucleation sites; however, the most serious problems arise at macro-scale level. Coating layers due to cladding and/or anodizing, and defects (machining marks, scratches etc.) induced by the manufacturing process have been found to be the principal sources of failure [12]. The fatigue performance of the 7075-T6 alloy is significantly reduced by the anodic oxidation process, and the degrading effect of the oxidation increases with the coating layer thickness. Such a detrimental effect is mainly ascribed to deep micro-cracks which form during the anodizing process. Moreover, the brittle nature of the oxide layer and the irregularities beneath the coating contribute to degradation [13].

Components with complex geometrical shapes, made of $\mathrm{Al}$ alloys, are usually obtained by closed-die forging of a billet, and are manufactured to obtain a good combination of strength, fatigue resistance and toughness. Some forging experiments have been performed on the 7050 alloy in agreement with AMS4333 requirements, and an alternative process [14], involving an intermediate warm deformation step at $200^{\circ} \mathrm{C}$ between the quenching and ageing steps, showed the possibility to improve fracture toughness without effects on YS and UTS. Results showed a more homogeneous and finer grain structure, after warm deformation, which can explain the increase in fracture toughness. 


\subsection{Al-Li Alloys}

The density of $\mathrm{Li}$ is very low $\left(0.54 \mathrm{~g} / \mathrm{cm}^{3}\right)$; thus, it reduces that of $\mathrm{Al}$ alloys ( $\sim 3 \%$ for every $1 \%$ of $\mathrm{Li}$ added). Moreover, $\mathrm{Li}$ is the unique alloying element that determines a drastic increase in the elastic modulus ( $\sim 6 \%$ for every $1 \%$ of added $\mathrm{Li}$ ).

$\mathrm{Al}$ alloys containing $\mathrm{Li}$ can be hardened by aging, and $\mathrm{Cu}$ is often used in combination with $\mathrm{Li}$ to form $\mathrm{Al}_{2} \mathrm{CuLi}$ and improve the mechanical properties [15]. In ternary $\mathrm{Al}-\mathrm{Cu}-\mathrm{Li}$ alloys, six ternary compounds have been identified; the most important among them are $\mathrm{T}_{1}\left(\mathrm{Al}_{2} \mathrm{CuLi}\right), \mathrm{T}_{2}\left(\mathrm{Al}_{6} \mathrm{CuLi}_{3}\right)$, and TB $\left(\mathrm{Al}_{15} \mathrm{Cu}_{8} \mathrm{Li}_{3}\right)$. The phases precipitating from the supersaturated solid solution depend on the $\mathrm{Cu} / \mathrm{Li}$ ratio [16,17]; the precipitation sequence has been described in ref. [18].

Al-Li alloys exhibit lower density and better specific mechanical properties than those of the 2XXX and 7XXX series; thus, they are excellent materials for aeronautic applications $[19,20]$. For example, the use of the 2060-T8 Al-Li alloy for fuselage panels and wing upper skin results in 7\% and $14 \%$ weight reduction if compared to the more conventional 2524 and 2014 alloys, respectively.

However, Li content higher than $1.8 \mathrm{wt} \%$ results in a strong anisotropy of mechanical properties resulting from texture, grain shape, grain size, and precipitates [21]. This was a serious drawback in the first two generations (GEN1 and (GEN2) of Al-Li alloys, which also had low toughness and corrosion resistance.

Al-Li alloys were first developed in the 1920s, and the 2020 alloy (GEN1) started to be produced in 1958 for the wing skins and empennage of the Northrop RA-5C Vigilante aircraft. The deep understanding of the relations between the microstructure and mechanical characteristics of these materials matured much later in the 1990s, leading to the production of the third generation (GEN3), a family of alloys with an outstanding combination of properties for aeronautic applications. The former generations of Al-Li alloys had a higher Li content and a lower density than GEN3 alloys, but suffered from high anisotropy associated with the precipitation of coarse Li phases, such as $\mathrm{T}_{2}[22,23]$.

Anisotropy has been partially reduced in GEN2 alloys through a suitable recrystallization texture and the tailoring of composition [24]. In GEN3 alloys with Li content between 1 and $1.8 \mathrm{wt} \%$, the anisotropy problem has been substantially overcome. These materials exhibit excellent mechanical properties; in particular, the specific stiffness ranges from 28.9 to $31.2 \mathrm{GPa} \mathrm{g}^{-1} \mathrm{~cm}^{3}$ and is much better than that of the $2 X X X(26.1-27.1)$ and $7 X X X(25.9-26.4)$ series. The phase $\delta^{\prime}\left(\mathrm{Al}_{3} \mathrm{Li}\right)$ is not present, and strengthening is mainly due to the precipitation of the $\mathrm{T}_{1}$ phase forming platelets on $\{111\} \mathrm{Al}$ planes [25-27].

The typical morphology of $\mathrm{T}_{1}$ precipitates is shown in Figure 3. In the first stage of precipitation up to the aging peak, $\mathrm{T}_{1}$ platelets have a constant thickness (one unit cell), then, it increases with a consequent decrease in mechanical performances [26]. Although some years ago $\mathrm{T}_{1}$ precipitates were believed to be unshearable by dislocations, more recent investigations through high-resolution electron microscopy evidenced sheared precipitates in deformed samples $[27,28]$. $\mathrm{T}_{1}$ precipitates are sheared in a single-step shearing event. The transition between shearing and by-passing is progressive, connected to the increase in $\mathrm{T}_{1}$ plate thickness, and takes place after peak ageing. The by-passing mechanism favours the homogenization of plasticity up to the macroscopic scale. Strain localization within the matrix can be minimized by changing the deformation mode from dislocation shearing to dislocation by-passing of the precipitates.

A great variety of $T_{1}$ microstructures can be been obtained, operating under different conditions of deformation and aging. The parameters of the $\mathrm{T}_{1}$ precipitate distributions have been systematically characterized and modelled by Dorin et al. [29].

In the conventional manufacturing route for producing aeronautic plates, stretching is carried out after solution heat treatment for relieving residual stresses due to quenching. The operation, which involves a plastic strain of about $5 \%$, also allows the obtainment of a homogeneous distribution of $\mathrm{T}_{1}$ precipitates after aging, since dislocations represent preferred sites for precipitate nucleation. Such homogeneous distribution is the key factor for the excellent mechanical properties of Al-Li alloys. Increasing the pre-strain induces a higher density of dislocations, i.e., the preferred $\mathrm{T}_{1}$ nucleation 
sites; thus, the average diffusion distance of alloying elements is reduced and the aging kinetics is accelerated. The benefits of stretching in Al-Cu-Li alloys saturate at pre-strains of 6-9\% [25].

Moreover, stretching prior to ageing is connected to a relevant technological problem: today, advances in rolling technology enable the production of plates with desired thickness, which is of great interest for manufacturing near-net-shape sections (e.g., tapered wing skins). The stretching of a tapered plate leads to a strain gradient, and it is necessary to know the maximum strain that can be achieved without fracture. Recently, Rodgers and Prangnell [30] have investigated the effect of increasing the pre-stretching of the Al-Cu-Li alloy AA2195 to higher levels than those currently used in industrial practice, focussing the attention on the behavior of the $\mathrm{T}_{1}$ phase. At the maximum pre-strain level before plastic instability (15\%), YS increased to $\sim 670 \mathrm{MPa}$ and ductility decreased to $7.5 \%$ in the T8 condition. In fact, increasing the pre-strain prior to ageing leads to a reduction in the strengthening provided by the $\mathrm{T}_{1}$ phase, in favour of an increase in the strain hardening contribution.

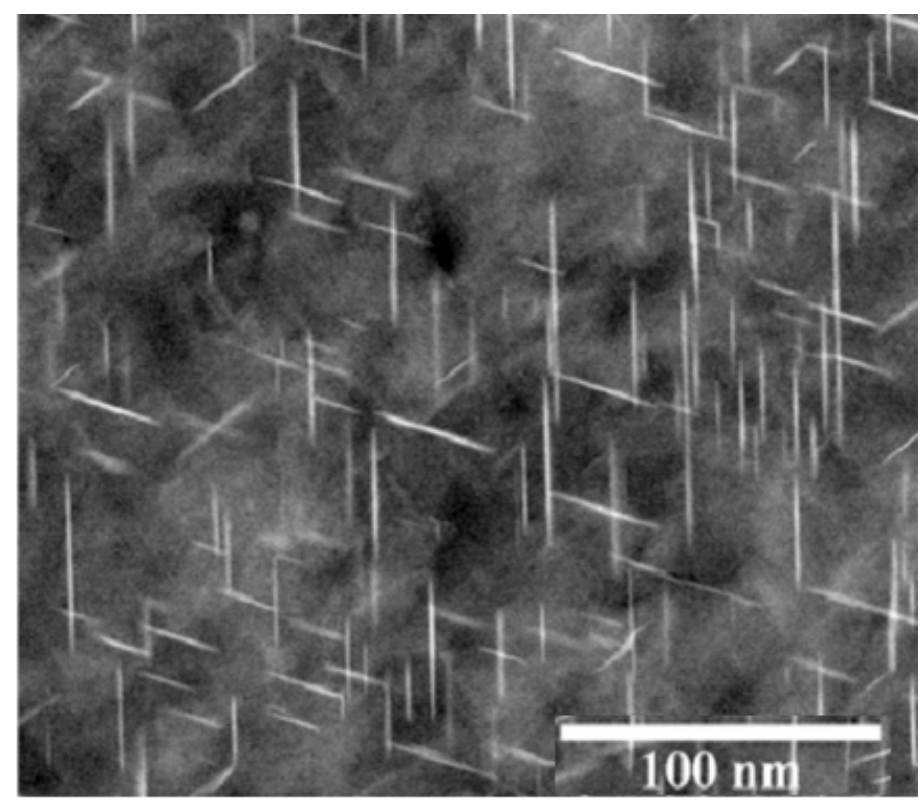

Figure 3. Typical morphology of $\mathrm{T}_{1}$ precipitates in $\mathrm{Al}-\mathrm{Cu}-\mathrm{Li}$ alloys.

In recent years, $\mathrm{Al}-\mathrm{Li}$ alloys have experienced a great development, mainly based on the tailoring of composition and the knowledge/control of the precipitation sequence of stable and metastable phases [19,31-36]. In the alloy compositions of major interest, $\mathrm{Cu}$ content is around $3 \mathrm{wt} \%$, $\mathrm{Li}$ is always below $1.8 \mathrm{wt} \%$ (in most recent alloys it does not exceeds $1.5 \mathrm{wt} \%$ ), $\mathrm{Mg}$ content varies in an extended range, and other elements, in particular $\mathrm{Ag}$ and $\mathrm{Zn}$, can be also added. Of course, the precipitation sequence depends on the specific composition. For example, a high Li content favors the formation of the metastable $\delta^{\prime}$ phase [27], while $\mathrm{Mg}$ leads to the precipitates typically present in the Al-Cu-Mg alloys, namely Guinier-Preston-Bagaryatsky (GPB) zones, $S^{\prime} / S$ [37,38]. In spite of strength increase, the presence of the $\delta^{\prime}$ phase is generally undesired because it is prone to shear localization, leading to poor toughness and ductility.

In a recent paper, Deschamps et al. [36] described the microstructural and strength evolution during long-term ageing $\left(3000 \mathrm{~h}\right.$ at $\left.85^{\circ} \mathrm{C}\right)$ of $\mathrm{Al}-\mathrm{Cu}-\mathrm{Mg}$ alloys with different contents of $\mathrm{Cu}, \mathrm{Li}$ and $\mathrm{Mg}$. They found that $\mathrm{T}_{1}$ is always the dominating phase in $\mathrm{T} 8$ condition, $\mathrm{S}$ phase is also present and, in the case of a high Li content, $\delta^{\prime}$ precipitates are observed. The examined alloys exhibit a very different level of microstructural stability during long-term ageing. Although the high Li alloy originally (T8 condition) has the lowest strength, its evolution leads to mechanical properties comparable with those of the other alloys after $3000 \mathrm{~h}$ of treatment. This is due to the precipitation of 
an additional fraction $(\sim 10 \%)$ of $\delta^{\prime}$ precipitates, whereas the two other alloys form a limited amount of metastable phases.

Another significant drawback to the GEN2 alloys is poor fracture toughness and ductility. Delamination cracking, which is a complex fracture mechanism involving initial transverse cracks with length comparable to grain size, is of great relevance in the fracture process. Delamination cracks along grain boundaries have been observed and described by many investigators [39-43]; Kalyanam et al. [44] systematically investigated the phenomenon in the 2099-T87 alloy, described the locations, sizes and shapes of delamination cracks and the extension of the primary macro-crack, and found that an isotropic hardening model with an anisotropic yield surface describes the constitutive behavior of the alloy.

In conclusion, GEN3 alloys have low density, excellent corrosion resistance, an optimal combination of fatigue strength and toughness, and are also advantageous in terms of cost in comparison to Carbon Fiber Reinforced Polymers (CFRP), which are considered as competitor materials to replace the traditional alloys of the 2XXX and 7XXX series in the design of new aircrafts.

\subsection{Aluminum Composites}

Composites with a metal, ceramic and polymer matrix are increasingly used in the aeronautic industry, replacing other materials (see Table 2). They are of relevant interest for applications in both structural and engine parts of aircrafts.

Metal matrix composites of light alloys $(\mathrm{Al}, \mathrm{Ti}, \mathrm{Mg})$ are usually reinforced by ceramics $\left(\mathrm{SiC}, \mathrm{Al}_{2} \mathrm{O}_{3}\right.$, $\mathrm{TiC}, \mathrm{B}_{4} \mathrm{C}$ ), in the form of long fibers, short fibers, whiskers or particles. Typically, these composites are prepared using $\mathrm{SiC}$ or $\mathrm{Al}_{2} \mathrm{O}_{3}$ particles instead of fibers, which are used only for special applications, such as some parts of Space Shuttle Orbiter [45]. In addition, the nature of reinforcement is a relevant factor to the production costs, and whiskers and ceramic particles seem to be a good compromise in terms of mechanical properties and costs $[46,47]$.

$\mathrm{Al}$ matrix composites, prepared with $\mathrm{SiC}$ and $\mathrm{Al}_{2} \mathrm{O}_{3}$ particle reinforcement, exhibit higher specific strength and modulus, fracture toughness, fatigue behavior, wear and corrosion resistance than the corresponding monolithic alloys. To further improve their mechanical properties, other types of reinforcements such as carbon nanotubes (CNTs) and graphene nano-sheets have been recently investigated [48-50]. If compared to the conventional reinforcements, CNTs and graphene are stronger and provide better damping and lower thermal expansion. A critical aspect is the optimization of reinforcement content because the properties of $\mathrm{Al}$ matrix composites strongly depend on such a parameter. For example, Liao et al. [49] found that the best characteristics are achieved with $0.5 \mathrm{wt} \%$ of multi-walled nanotubes.

In addition to high mechanical properties, good corrosion resistance is a requirement of $\mathrm{Al}$ composites. The topic has been extensively investigated for many years (e.g., see [51-53]); however, it is not yet completely clear how the presence of reinforcing phases influences the corrosion resistance and mechanisms. It is a common opinion that galvanic corrosion may take place due to the contact between reinforcement particles and the matrix: galvanic coupling between $\mathrm{Al}$ and ceramic particles has been detected, with the reinforcement acting as an inert electrode upon which $\mathrm{O}_{2}$ and/or $\mathrm{H}^{+}$reductions occur [54].

Anyway, composites are more susceptible to pitting corrosion than the corresponding monolithic alloys, and preferential attack occurs at the reinforcement-matrix interface [55,56]. The phenomenon is enhanced by the presence of precipitates, in particular when they are located at the junction between the reinforcement particles and the metal matrix [57].

\subsection{Advanced Joining Techniques for Aluminum Alloys}

The development of innovative joining techniques is a relevant aspect for the aeronautic applications of Al alloys. Recently, Friction Stir Welding (FSW) gained increasing attention in the aerospace industry (e.g., airframes, wings, fuselages, fuel tanks), and a lot of research efforts have 
been devoted to one of its variants, namely, Friction Stir Spot Welding (FSSW) [58-65]. This method is an alternative to resistance welding, riveting, and adhesive bonding in the fabrication of aircraft structures, and allows the joining of components made of $\mathrm{Al}$ alloys with lower costs and better strength than conventional techniques. Welding time, tool rotation speed, tool delve depth, tool plunge speed and tool exit time are crucial parameters which should be properly optimized [63-65].

A serious problem is represented by the hole resulting from the welding process, which strongly weakens the joint strength. A novel technique, Refill Friction Stir Spot Welding (RFSSW) [66,67], allows us to overcome this drawback through the filling of the hole. RFSSW employs a tool made of a pin and a sleeve, and its procedure is described in detail in the paper of Kluz et al. [68].

RFSSW is very useful for joining materials whose microstructure can be remarkably changed by conventional welding processes, especially the alloys of $2 \mathrm{XXX}$ and 7XXX series.

Many advantages are related to spot welding, causing a decline in the riveting and gluing of $\mathrm{Al}$ alloys: (i) the drilling of parts and the use of rivets as additional fasteners are not required; (ii) a great resistance to corrosion can be achieved for welded joints; (iii) the possibility to perform simple repairs of joints; (iv) no part of the joint extends beyond the surface of the joined elements. The optimization of the RFSSW parameters to get the best mechanical performances of joints has been studied by many authors [66-70].

\section{Titanium Alloys}

Owing to their excellent specific strength and corrosion resistance, Ti alloys are increasingly used for manufacturing structural parts of aircrafts. They are also employed in engine sections operating at intermediate temperature $\left(500-600{ }^{\circ} \mathrm{C}\right)$.

Ti alloys can be divided into three main classes $(\alpha, \beta$ and $\alpha-\beta)$. Independently of the specific class, the mechanical properties of Ti alloys depend on $\mathrm{O}$ and $\mathrm{N}$ in solid solution [71,72]. The solubility of these interstitial elements in both $\alpha$ and $\beta$ phases is high, increases with temperature and the part of the gas absorbed at high temperature remains entrapped in the metal after cooling, causing lattice distortion. In addition to modifying the mechanical properties, this phenomenon plays a role also in manufacturing processes and stress relieving heat treatments. X-ray diffraction experiments on the Ti6Al4V alloy carried out up to $600{ }^{\circ} \mathrm{C}$ in vacuum or different atmospheres demonstrated that the effects of $\mathrm{O}$ and $\mathrm{N}$ are synergic with the intrinsic anisotropic thermal expansion in determining the distortion of the hexagonal lattice [73-76].

The surface integrity of machined aeronautical components made of Ti alloys [77-79] also represents a critical problem. The cutting of Ti alloys generates an enormous amount of heat at the chip-tool interface, which is not suitably dissipated owing to the low thermal conductivity; this causes surface damage and residual stresses [80].

\section{1. $\alpha-T i$}

In general, $\alpha$-Ti alloys have better creep behavior and corrosion resistance than $\beta$-Ti alloys [81], therefore, some of them (e.g., Ti-3Al-2.5V, Cp-Ti, Ti-5-2.5, Ti-8-1-1, Ti-6-2-4-2S, IMI829) are commonly used to make compressor disks and blades of aeronautic engines.

In order to improve the microstructural stability of $\alpha$-Ti alloys at increasing temperature, and, consequently, their mechanical performances, different compositions have been studied by adding $\mathrm{Al}$, $\mathrm{Sn}, \mathrm{Zr}$ and $\mathrm{Si}$. The results are not completely satisfying because the achievement of some advantages is often accompanied by drawbacks. For instance, Jiang et al. [82] modified the composition of a Ti-25Zr alloy by adding $\mathrm{Al}$ up to $15 \%$ and found that the YS increase is accompanied by a reduction of ductility. 


\section{2. $\beta$-Ti}

$\beta$-Ti alloys exhibit higher strength and fatigue behavior than the $\alpha$-Ti alloys, thus they are employed for high-stressed aircraft components, e.g., landing gear and springs are currently manufactured using Ti-15V-3Cr-3Al-3Sn and Ti-3Al-8V-6Cr-4Mo-4Zr alloys [83], while Ti-10V-2Fe-3Al, Ti-15Mo-2.7Nb-3Al-0.2Si, Ti-5Al5V5Mo3Cr0.5Fe and Ti-35V-35Cr are applied in airframe parts [84].

A drawback of these materials is the relatively low ductility, which can be mitigated through tailoring the composition (Ti-1300 [85]) and suitable heat treatments (Ti-6Al-2Sn-2Zr-2Cr-2Mo-Si [86]).

\section{3. $\alpha-\beta-T i$}

Ti-6Al-4V is the most used Ti alloy owing to its excellent combination of mechanical properties (strength, fracture toughness and ductility) and corrosion resistance [87]. Moreover, $\mathrm{Zr}$ addition further improves its strength through the solid solution hardening mechanism; Jing et al. [88] showed that hardness is increased to $420 \mathrm{HV}$ and YS to 1317MPa by adding $20 \mathrm{wt} \% \mathrm{Zr}$ at the expense of ductility (elongation ratio drops to $\sim 8 \%$ ).

Ti-6Al-2Zr-2Sn-3Mo-1Cr-2Nb, Ti-6Al-2Sn-2Zr-2Cr-2Mo-Si and ATI 425 are other $\alpha-\beta-T i$ alloys widely used for manufacturing aircraft parts such as fuselage, landing gear and compressor disks.

\subsection{Ti Composites Reinforced with SiC Fibers}

Ti composites are materials of great interest for aeronautic applications and, in particular, attention has been focused on those reinforced with long ceramic fibers [89-102]. Among them, the Ti6Al4V-SiC $f$ composite is a promising material for turbine components and structural high-stressed parts.

Figure 4a shows the stratified structure of the SiC fibers: a C layer of about $3 \mu \mathrm{m}$ separates the $\mathrm{SiC}$ fiber from the Ti6Al4V matrix. The composite is commonly prepared by Hot Isostatic Pressing (HIP) or Roll Diffusion Bonding (RDB) of Ti6Al4V sheets alternated with SiC fiber layers [99,102]; the resulting structure is displayed in Figure $4 \mathrm{~b}$.

The $\mathrm{Ti} 6 \mathrm{Al} 4 \mathrm{~V}-\mathrm{SiC}_{\mathrm{f}}$ composite is a promising material for mechanical components operating at medium temperatures, especially turbine blades and structural high-stressed parts of aeronautic engines. The performances mainly depend on the fiber-matrix interface and chemical reactions occurring during the manufacturing process and in-service life, when it is exposed for a long time to temperatures around $600^{\circ} \mathrm{C}$.

Direct contact of the Ti6Al4V matrix with $\mathrm{SiC}$ induces the formation of brittle compounds like $\mathrm{Ti}_{5} \mathrm{Si}_{3}$, which deteriorate the mechanical behavior of the composite $[103,104]$, therefore the fibers are coated with a thin $\mathrm{C}$ layer. This coating hinders chemical reactions, preserves the fiber integrity, reduces the interfacial debonding and deflects the propagation of micro-cracks along the fiber. However, when the composite is operating for a long time at medium-high temperatures, $\mathrm{C}$ diffuses into the matrix, forming TiC. The TEM micrograph in Figure 5 a displays TiC particles of $\sim 200 \mathrm{~nm}$ forming an irregular layer around a fiber which has grown during the fabrication process at high temperature.

X-ray photoelectron spectroscopy (XPS), Auger electron spectroscopy (AES) and scanning photoemission microscopy (SPEM) analyses, carried out before and after heat treatments at $600{ }^{\circ} \mathrm{C}$ of up to $1000 \mathrm{~h}$, evidenced the stability of the fiber-matrix interface [94-97,101]. The fiber-matrix interface is also stable after prolonged heat treatments because a thin TiC layer forms all around the $\mathrm{C}$ coating during the fabrication process, hindering further $\mathrm{C}$ diffusion towards the matrix and delaying interface degradation. This is due to the fact that $\mathrm{C}$ diffusion through $\mathrm{TiC}$ is much slower than through $\mathrm{Ti}$ (for $\mathrm{C}$ in Ti, the diffusion parameters are $D_{0}=5.1 \times 10^{-4} \mathrm{~m}^{2} \mathrm{~s}^{-1}$ and $Q=182 \mathrm{~kJ} \mathrm{~mole}^{-1}$ [105], whereas for $\mathrm{C}$ in TiC, $D_{0}=4.1 \times 10^{-8} \mathrm{~m}^{2} \mathrm{~s}^{-1}$ and $Q=207 \mathrm{~kJ} \mathrm{~mole}^{-1}$ [106]).

If the material is heated in air, $\mathrm{C}$ atoms present in the core and the coating of fibers may react with $\mathrm{O}$, forming $\mathrm{CO}$ and $\mathrm{CO}_{2}$; in this case, a groove is observed all around the fibers (Figure $5 b, c$ ) and in the fibers' core. Therefore, the surface of the composite during in-service life must be protected to avoid direct contact with $\mathrm{O}$ in the air. 


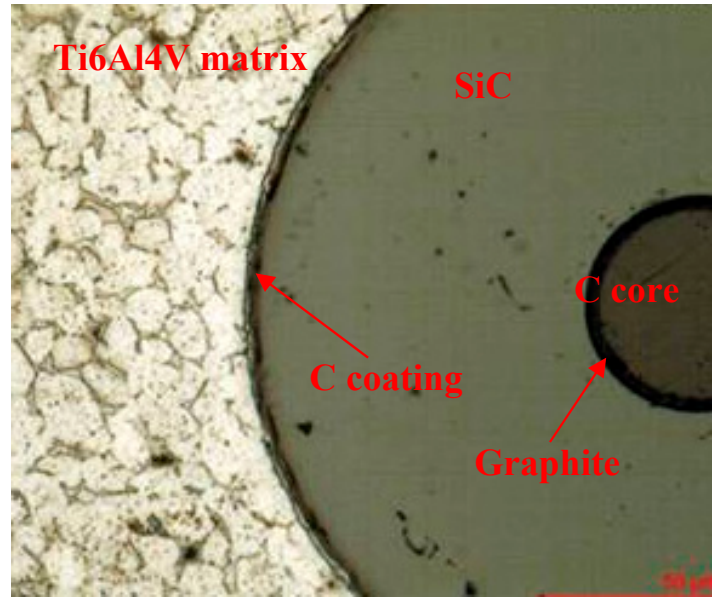

(a)

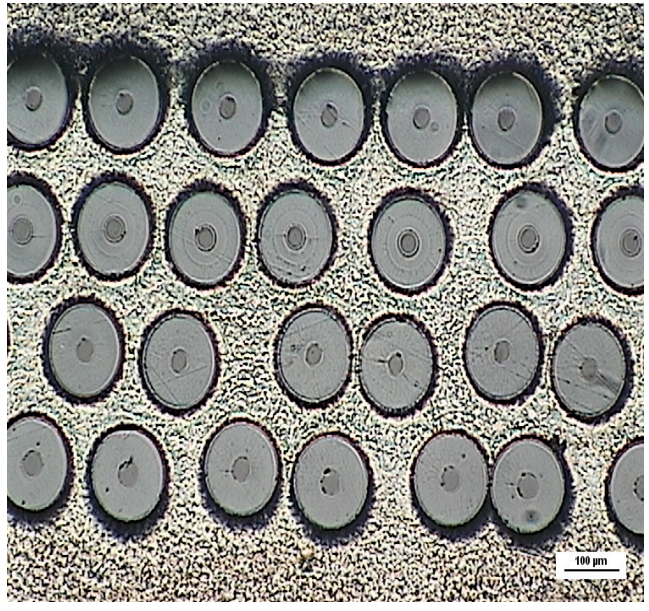

(b)

Figure 4. Stratified structure of $\mathrm{SiC}$ fibers (a). Typical morphology of $\mathrm{Ti}_{6 \mathrm{Al}} \mathrm{V}$-SiC $\mathrm{C}_{\mathrm{f}}$ composite (b).

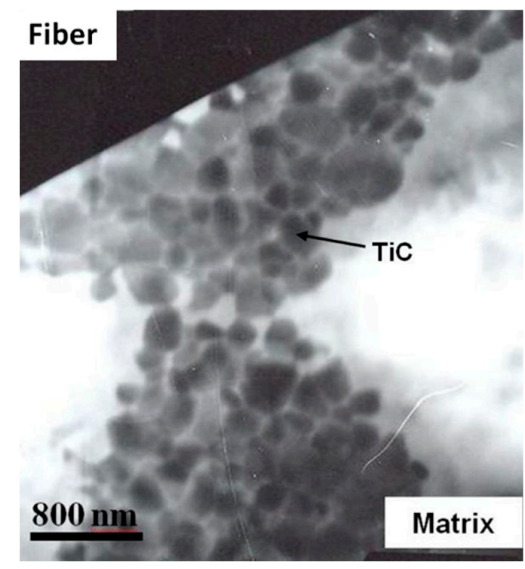

(a)

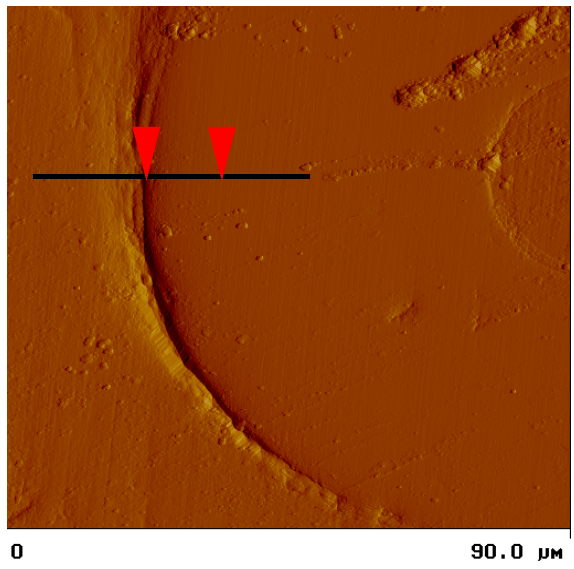

(b)

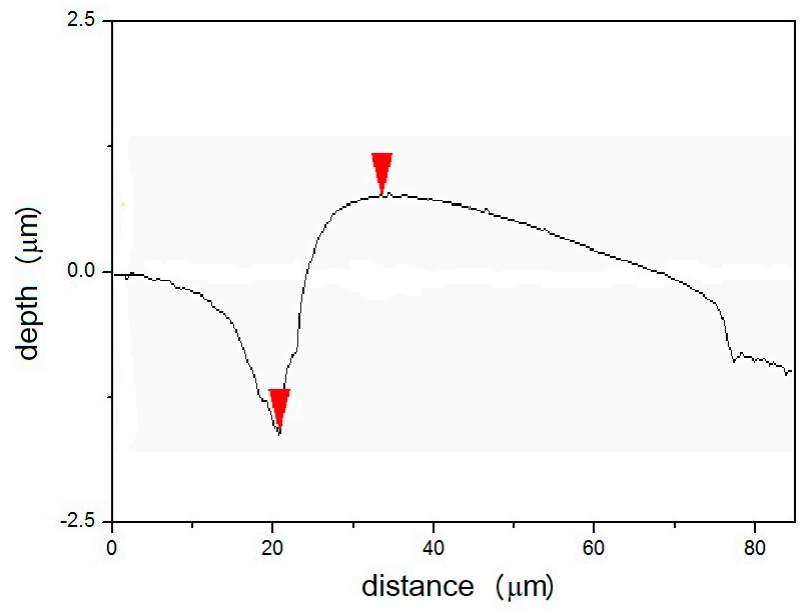

(c)

Figure 5. The TEM micrograph shows TiC particles forming an irregular layer around a fiber (a). AFM (Atomic Force Microscopy) evidences a groove all around the fiber, in correspondence to the $\mathrm{C}$ coating after a treatment of $1 \mathrm{~h}$ at $600{ }^{\circ} \mathrm{C}$ in air (b). The depth profile measured along the line in $(\mathbf{b})$ is displayed in (c). AFM observations were carried out using a Multimode III of Digital Instruments in contact mode and $\mathrm{Si}_{3} \mathrm{~N}_{4}$ tip. 
The stability of the fiber-matrix interface leads to the stability of the mechanical properties. YS, UTS and Young's modulus $E$, determined from tensile tests carried out at room temperature on the Ti6Al4V-SiC $\mathrm{C}_{\mathrm{f}}$ composite in as-manufactured condition and after different heat treatments, are reported in Figure 6a [96]. It is clear that the mechanical properties are scarcely affected by heat treatments, even in the most severe conditions. Moreover, fracture surfaces show plastic deformation of the matrix and pull-out of the fibers, i.e., a correct load transfer from the matrix to the fibers (Figure 6b).

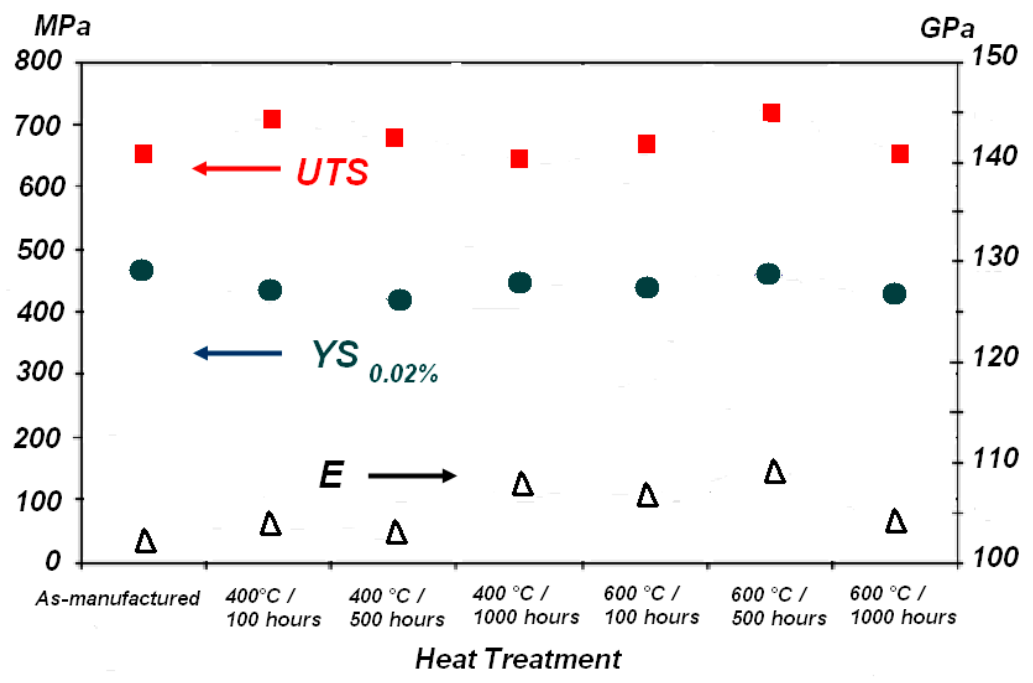

(a)

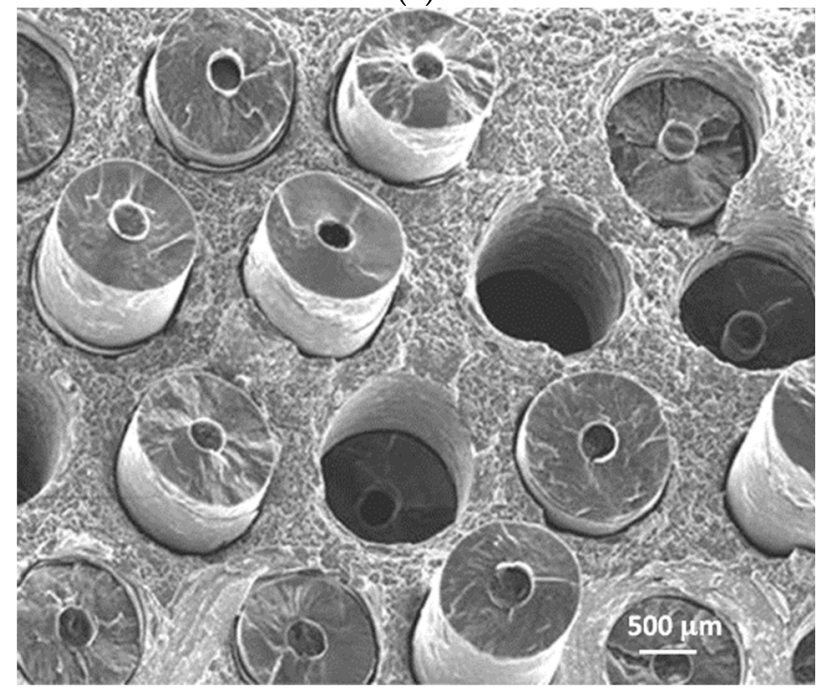

(b)

Figure 6. Yield stress (YS), ultimate tensile strength (UTS) and Young's modulus $E$ determined from tensile tests at room temperature carried out on the $\mathrm{Ti6} \mathrm{Al} 4 \mathrm{~V}-\mathrm{SiC}_{\mathrm{f}}$ composite in as-manufactured condition and after the indicated heat treatments (a). Figure 6a was redrawn from data reported in [94]. Fracture surface of a sample exposed at $600^{\circ} \mathrm{C}$ for $1000 \mathrm{~h} \mathrm{(b).}$

Figure 7 compares the results obtained from fatigue tests carried out on the material in as-manufactured condition and after $1000 \mathrm{~h}$ at $600{ }^{\circ} \mathrm{C}$. Also, these data confirm the good stability of composite mechanical properties after long-term exposure to high temperature. 


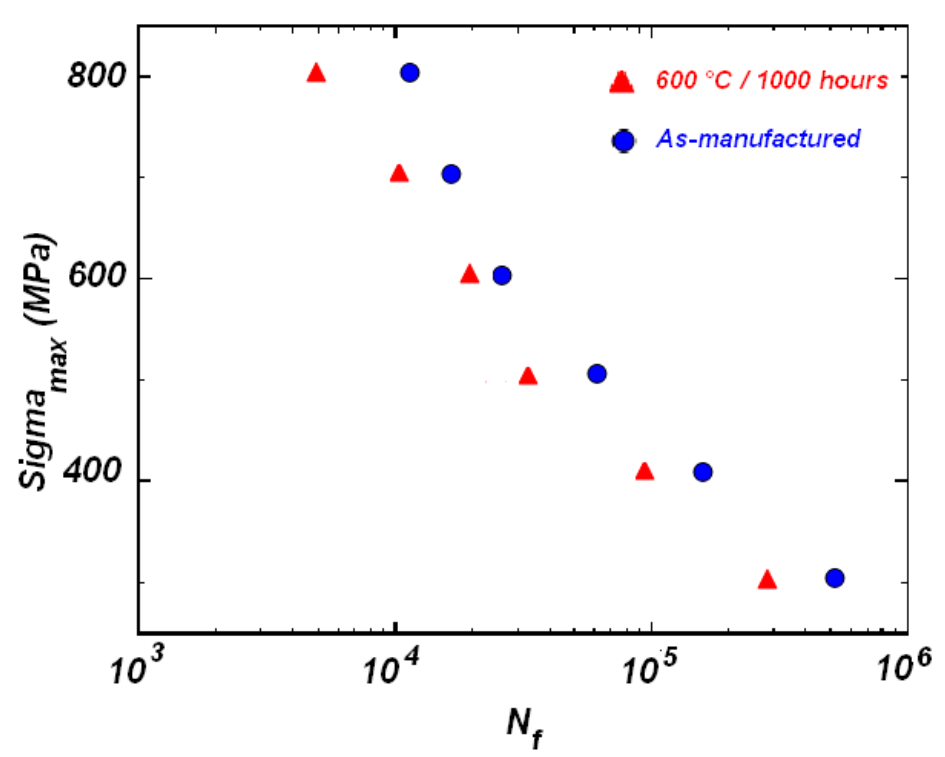

Figure 7. Curves determined from fatigue tests carried out on the material in as-manufactured condition and after $1000 \mathrm{~h}$ at $600{ }^{\circ} \mathrm{C}$.

\section{Magnesium Alloys}

$\mathrm{Mg}$ is the lightest metal used in structural applications and exhibits excellent castability [107], with good fluidity and less susceptibility to hydrogen porosity than other cast metals such as Al alloys [108]. In fact, wrought $\mathrm{Mg}$ alloys have better mechanical properties than casting alloys; however, the higher asymmetry in plastic deformation represents a serious problem [109]. For this reason, casting is the principal way for manufacturing $\mathrm{Mg}$ components, and various processes are currently used for producing castings (a literature overview can be found in ref. [107]). Other relevant advantages of $\mathrm{Mg}$ are its abundance and recyclability [110].

On the other hand, the poor mechanical properties and low corrosion resistance of $\mathrm{Mg}$ alloys limit their use in manufacturing parts of aircrafts, even if some alloys (AZ91, ZE41, WE43A and ZE41) are commonly used for gear boxes of helicopters. For commercial casting alloys, the tensile yield strength is in the range $100-250 \mathrm{MPa}$ and the ductility at room temperature is limited (elongation in the range $2-8 \%$ ) [111,112].

The strategies for strengthening Mg alloys mainly rely on: (i) grain refinement, (ii) precipitation of second phases, and (iii) control of microstructural features on a nano-scale.

The first approach is based on techniques for obtaining ultrafine grains, smaller than $1 \mu \mathrm{m}$ [113-115]. The numerous grain boundaries represent obstacles for dislocation motion, thus $\mathrm{Mg}$ alloys can reach YS values of about $400 \mathrm{MPa}$, but strength is reduced when grain growth occurs at relatively low temperature $(0.32 \mathrm{Tm})$ [114]. Another drawback is the fact that grain refining tends to suppress deformation twinning, which is an important strengthening mechanism together with dislocation slip [116-119].

The precipitation of second phases involves the composition tailoring of $\mathrm{Mg}$ alloys by adding elements like $\mathrm{Al}, \mathrm{Zn}, \mathrm{Zr}$ and rare earths. Moreover, the increase in $\mathrm{Al}$ content also remarkably improves the corrosion resistance $[120,121]$.

As shown in Figure 8, YS and UTS of Mg alloys increase with Zn content up to $4 \mathrm{wt} \%$, while for higher values they remain constant or slightly decrease [122]. The precipitation of $\mathrm{Mg}_{\mathrm{x}} \mathrm{Zn}_{\mathrm{y}}$ phases induces relevant hardening and guarantees an interesting combination of good strength and ductility. However, for the corrosion resistance of $\mathrm{Mg}-\mathrm{Zn}$ based curves determined from fatigue tests carried out on the material in as-manufactured condition and after $1000 \mathrm{~h}$ at $600^{\circ} \mathrm{C}$, the alloy decreases as $\mathrm{Zn}$ content in the alloy increases [123] due to the cathodic effect of the $\mathrm{Mg}_{\mathrm{x}} \mathrm{Zn}_{\mathrm{y}}$ phases, whose volume increases with $\mathrm{Zn}$. 
Homma et al. [124] developed $\mathrm{Mg}-6 \mathrm{Zn}-0.2 \mathrm{Ca}-0.8 \mathrm{Zr}$ alloys, and found that $\mathrm{Zr}$ addition is beneficial to refine the grain size as well as to disperse fine and dense $\mathrm{MgZn}$. precipitates containing $\mathrm{Ca}$ and Zr. Mechanical properties are enhanced through the combination of texture strengthening, grain size refinement and precipitation strengthening.

$\mathrm{Mg}$ alloys containing rare earths can exhibit high strength at both room and elevated temperatures; the effects of $Y$ on mechanical properties have been extensively investigated by Xu et al. [125], who observed that $\mathrm{Mg}-\mathrm{Zn}-\mathrm{Y}$ phases are formed at the grain boundaries. The phases vary with $\mathrm{Y}$ content: when $\mathrm{Y}$ is $1.08 \mathrm{wt}$ \%, the alloy mainly contains I-phase, whereas for higher $\mathrm{Y}$ content (1.97-3.08 wt.\%) $\mathrm{W}$-phase is also present. The alloy with $1.08 \mathrm{wt} . \%$ of $\mathrm{Y}$ has the highest strength because I-phase is closely bonded with the Mg matrix and retards the basal slip. Since W-phase easily cracks under deformation, $\mathrm{Y}$ contents in the range 1.97-3.08 wt.\% induce the degradation of mechanical properties.

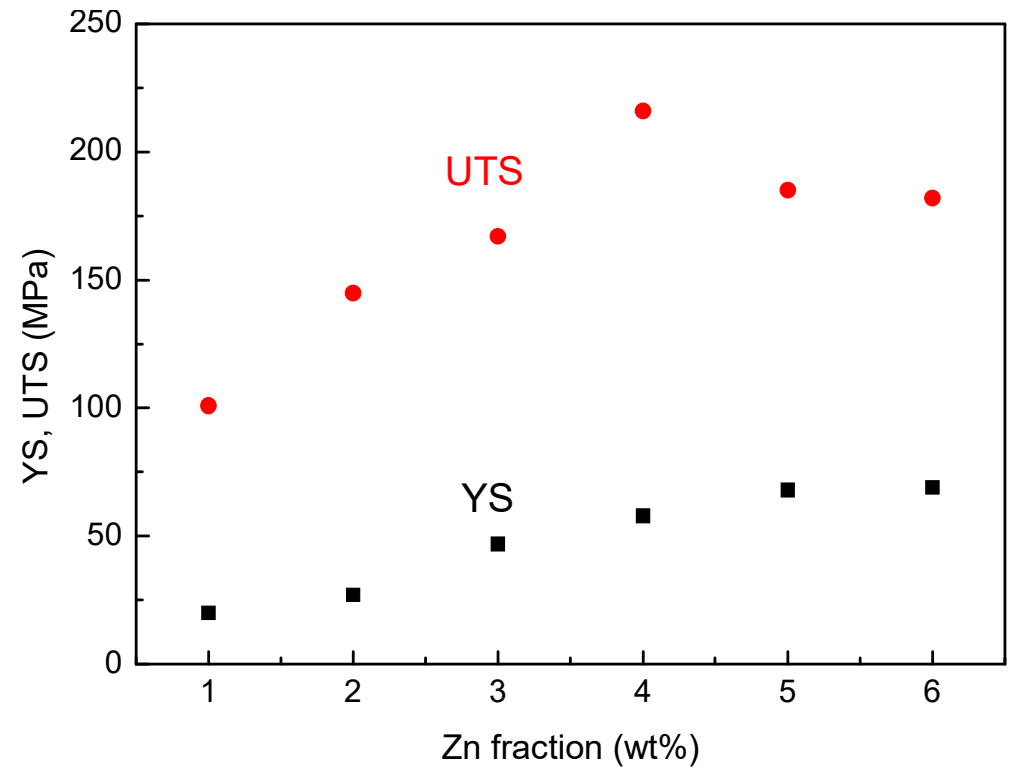

Figure 8. YS and UTS of Mg alloys vs. Zn content. Data are taken from [122].

An effective method to produce ultra-strong $\mathrm{Mg}$ alloys (YS = $575 \mathrm{MPa}$, UTS = $600 \mathrm{MPA})$ with uniform elongation $(\sim 5.2 \%)$ has been proposed by Jian et al. [126], and is based on stacking faults (SFs) with nanometric spacings, induced by hot rolling. These investigators studied a T4 treated $\mathrm{Mg}-8.5 \mathrm{Gd}-2.3 \mathrm{Y}-1.8 \mathrm{Ag}-0.4 \mathrm{Zr}$ (wt\%) alloy which was subjected to increasing deformation up to $88 \%$ of reduction and observed that the mean distance between SFs decreases with thickness reduction. Since SFs act as barriers for dislocation motion, a higher SFs density leads to an increase in strength.

In addition to grain refinement, the precipitation of second phases and the control of microstructural features on a nano-scale, non-traditional approaches have been also considered to obtain high strength in $\mathrm{Mg}$ alloys, for instance rapid solidification and powder metallurgy achieved $\mathrm{YS} \cong 600 \mathrm{MPa}$ in a $\mathrm{Mg}-\mathrm{Zn}-\mathrm{Y}$ alloy with uniform distribution of ordered structures [127]. However, the process involves a significant loss of ductility and is difficult to transfer from a lab scale to an industrial scale.

\section{Steels}

Ultra-High Strength Steels (UHSS) are commonly used for manufacturing aircraft parts such as landing gears, airframes, turbine components, fasteners, shafts, springs, bolts, propeller cones and axles. Some of them exhibit very high YS values, e.g., 300M (1689 MPa), AERMET100 (1700 MPa), $4340(2020 \mathrm{MPa})$; however, there is a tendency to progressively replace these materials by composites. The reason is related to their low specific strength and corrosion resistance. Moreover, UHSS are weakened by $\mathrm{H}$ atoms, which favor crack growth and micro-void formation with consequent localized deformation and failure [128]. 
Recently, Oxide Dispersion Strengthened (ODS) steels have attracted the attention of aeronautic industries. A lot of scientific work has been devoted to ODS ferritic steels, because they are promising candidate materials for applications in nuclear reactors [129,130]. ODS steels are strengthened through a uniform dispersion of fine (1-50 nm) oxide particles which hinder dislocation motion and inhibit recrystallization. High-temperature performances are also improved by refining the ferritic grain in combination with oxide dispersion strengthening [131,132].

Usually, ODS steels are prepared by high-energy mechanical alloying (MA) of steel powders mixed with $\mathrm{Y}_{2} \mathrm{O}_{3}$ particles, followed by hot isostatic pressing (HIP) or hot extrusion (HE) $[133,134]$ and annealing at $\sim 1100{ }^{\circ} \mathrm{C}$ for $1-2 \mathrm{~h}$. A drawback of the aforesaid procedure is that the final high temperature annealing causes the equiaxed nanometric grains obtained by MA to transform into grains with a bimodal grain size distribution, involving anisotropic mechanical properties and a remarkable decrease in hardness, YS and UTS [135]. Nano-ODS steels were also produced via Spark Plasma Sintering (SPS), by exploiting the high heating rate, low sintering temperature and short isothermal time at sintering temperature $[136,137]$; however, the difficulty in manufacturing large mechanical parts by SPS is a clear shortcoming of the technique.

Some of present authors [138,139] prepared a nano-ODS steel by means of low-energy MA without the annealing stage at high temperature, obtaining a microstructure of fine equiaxed grains. As shown in Figure 9 taken from ref. [138], ODS steel exhibits higher YS and UTS than the unreinforced one, even if the difference progressively decreases above $400{ }^{\circ} \mathrm{C}$ because dislocations can easier get free from nano-precipitates. Mechanical properties are also better up to $500^{\circ} \mathrm{C}$ than those of ODS steel prepared through the conventional route. The data of a conventional ODS steel (ODS*) reported in Figure 9 are taken from [140]; L and T indicate samples taken along longitudinal and transverse direction, respectively. Since precipitate distribution is not homogeneous in ODS steel prepared by low-energy MA, YS and UTS remarkably decrease when the strengthening role played by precipitates becomes dominant (above $500{ }^{\circ} \mathrm{C}$ ).

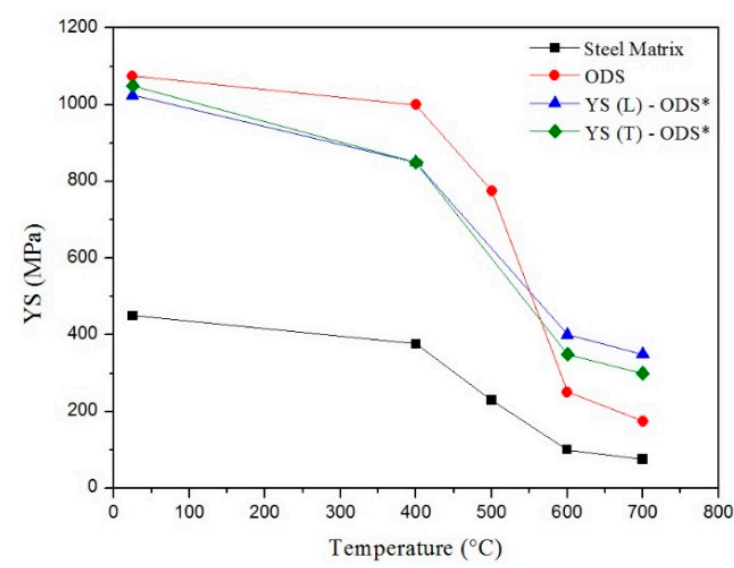

(a)

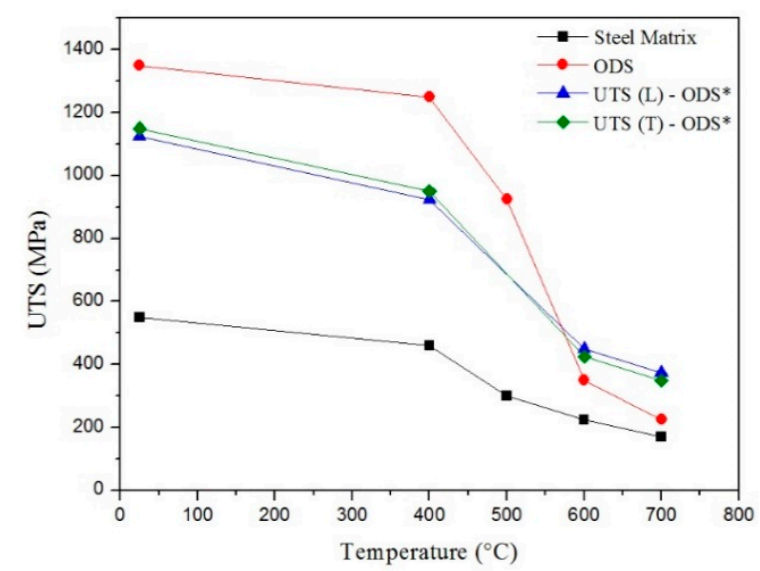

(b)

Figure 9. YS (a) and UTS (b) of ODS steel prepared by low-energy MA are compared with those of the unreinforced steel (steel matrix) and of another material (ODS*), prepared through the conventional route (high-energy MA, hot extrusion at $1100{ }^{\circ} \mathrm{C}$, annealing of $1.5 \mathrm{~h}$ at $1050{ }^{\circ} \mathrm{C}$ ). $\mathrm{L}$ and $\mathrm{T}$ indicate samples taken along longitudinal and transverse direction, respectively. The figure is taken from [138].

\section{Ni-Based Superalloys}

Ni-based superalloys with a biphasic structure $\left(\gamma+\gamma^{\prime}\right)$ are usually employed to manufacture parts of aeronautic engines such as blades and rotors operating in the highest temperature range (1100-1250 ${ }^{\circ} \mathrm{C}$ ). Three topics of great industrial relevance will be discussed: (i) microstructural stability; (ii) manufacturing parts of complex geometry; (iii) welding of superalloys. 


\subsection{Microstructural Stability}

In order to increase the working efficiency of aero-engines, they must operate at higher temperature, thus the high temperature properties of superalloys are very important, especially the microstructural and mechanical stability.

Recently, some authors have evidenced an early stage of microstructural instability in both single crystal (PWA1482) [141,142] and directionally solidified (IN792 DS) [143] Ni-based superalloys, connected to the re-arrangement of dislocation structures induced by heating to moderate temperature $\left(\sim 500^{\circ} \mathrm{C}\right)$. Dislocation cells present in the precipitate free $(\mathrm{PF})$ zones of the matrix (Figure 10a,b) grow to form cells of larger size; the process proceeds by steps modifying dislocation density and average distance of pinning points; finally the growth stops when cells reach a size comparable to that of the corresponding PF zone.

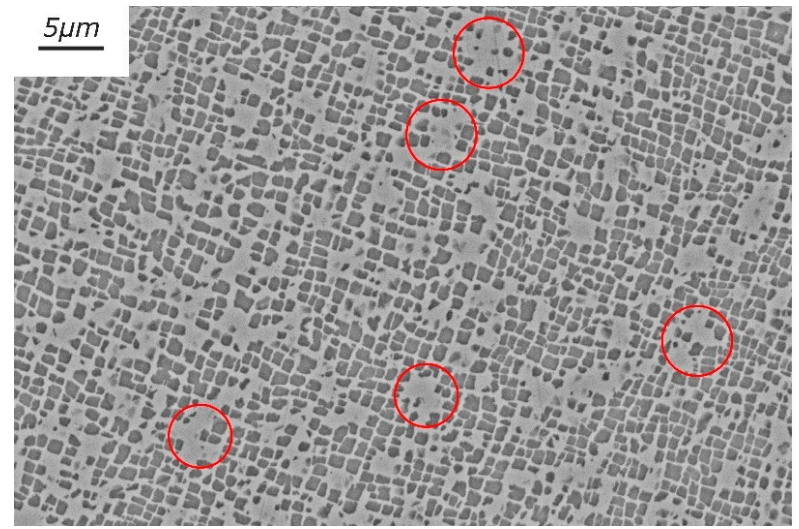

(a)

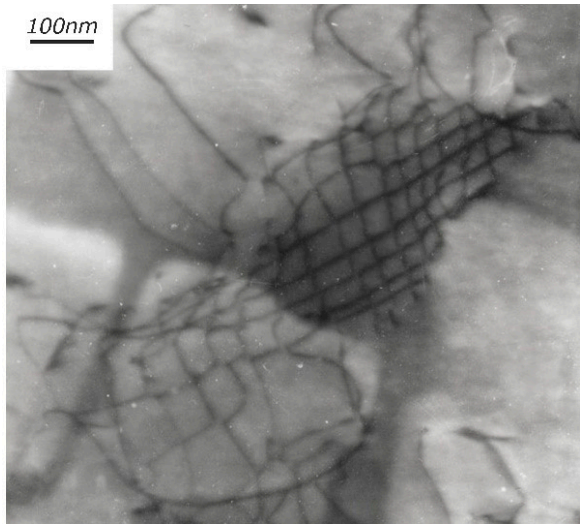

(b)

Figure 10. PWA 1483 superalloy. Precipitate free zones (PFZ) are indicated by red circles (a). The TEM micrograph in (b) displays a network of dislocations inside a PFZ. Figure is taken from [142].

In general, the coarsening of the ordered $\gamma^{\prime}$ phase and changes in its morphology (rafting) are the most relevant phenomena leading to the degradation of mechanical performances at high temperature. As shown in Figure 11a,b, at high temperature and under an applied stress, the $\gamma^{\prime}$ particles, which usually have a cuboidal shape (a), tend to coalesce, forming layers known as rafts (b). At very high temperatures (above $1050{ }^{\circ} \mathrm{C}$ ), rafting takes place during the initial part $(1-3 \%$ ) of the creep life, while at lower temperature $\left(\sim 900^{\circ} \mathrm{C}\right)$ it only completely develops during the tertiary creep.

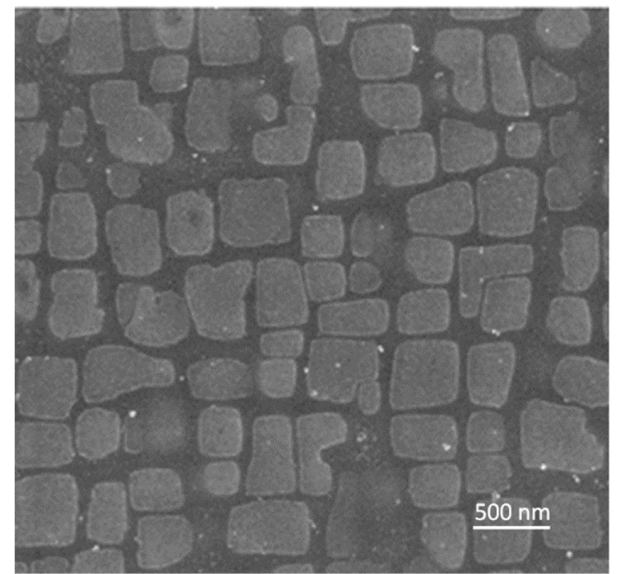

(a)

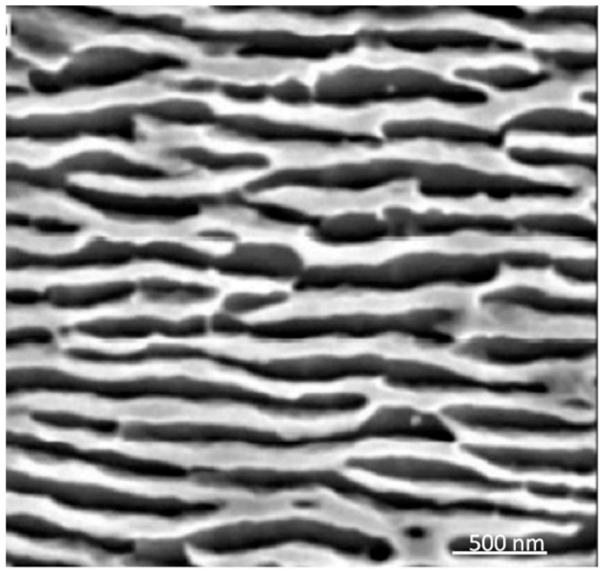

(b)

Figure 11. The typical morphology of the $\gamma^{\prime}$ phase in Ni-based superalloys (a). Results changed by rafting $(\mathbf{b})$. 
At the beginning of creep, dislocations are forced to bow in the narrow matrix channels where all the plastic strain occurs, while $\gamma^{\prime}$ phase deforms elastically [144]. The progressive increase in plastic deformation in the $\gamma$ phase enhances internal stresses, leading to dislocation shearing of $\gamma^{\prime}$ particles during the tertiary creep. Of course, $\gamma^{\prime}$ particle coarsening involves the degradation of creep properties.

Refractory elements, such as $\mathrm{Re}, \mathrm{Ta}, \mathrm{Ru}$ and $\mathrm{W}$, are today added to Ni-based superalloys to improve their high temperature properties [145-148]. These elements provide good creep strength because their low atomic mobility retards dislocation climb in both $\gamma$ and $\gamma^{\prime}$ phases. Re concentrates mostly in the $\gamma$ matrix, forming nanometric atomic clusters with short-range order, which reduce rafting during creep and hinder dislocation movement. Moreover, Re promotes the precipitation of topologically close-packed phases (TCP) [149]. The partition of refractory metals between the $\gamma$ and $\gamma^{\prime}$ phases occurs and is dependent on their relative contents in the alloy composition. For instance, the amount of Re in the $\gamma^{\prime}$ phase increases by increasing $\mathrm{W}$ content in the alloy.

In general, these alloys have more than seven alloying elements in their composition, and the addition of further elements may strongly alter segregation profiles in casting, thus solidification has been extensively investigated, focusing the attention on the partition of elements in solid and liquid during cooling [150-152]. Guan et al. [151] reported that liquidus and solidus decrease by increasing $\mathrm{Cr}$ in Re-containing alloys, and changes of these critical lines induced by $\mathrm{Ru}$, were observed by Zheng et al. [153].

The addition of $\mathrm{B}$ and $\mathrm{N}$ to superalloys containing refractory metals affects solidification defects. For instance, $\mathrm{N}$ has been proven to increase the micro-porosity [154], while B retards grain boundary cracking and reduces the size of carbides with consequent improvement in mechanical properties [155].

Today, grain boundary engineering (GBE) represents an interesting field of research that could contribute to the reduction of inter-crystalline damage to superalloys and, in general, to the improvement of their mechanical properties [156]. Annealing twin boundaries are very important for GBE owing to their low energy. Recently, Jin et al. [157] reported an interesting result about the correlation of the annealing twin density in Inconel 718 with grain size and annealing temperature. These investigators showed that twin density mainly depends on the original one in the growing grains, but not on the temperature at which they grow, namely no new twin boundaries form during the grain growth process.

\subsection{Manufacturing Parts of Complex Geometry}

An aspect of relevant importance for these materials is the possibility of manufacturing aeronautic components of complex geometry. Owing to their high hardness and poor thermal conductivity, the machining of superalloys is challenging and novel techniques (e.g., see [158-162]) have been investigated. For example, laser drilling and electrical discharge machining are used to produce effusion cooling holes in turbines blades and nozzle guide vanes [158]. Even though the description of such novel techniques goes beyond the scope of the current paper, it is worth noting that recently there is an increasing interest of aeronautic industry in the use of Additive Manufacturing (AM) for the production of Ni-based high-temperature components. Among the different AM technologies selective laser melting (SLM) and selective electron beam melting (SEBM) are the most interesting as they enable the preparation of almost fully dense metal parts of complex shape, starting from a computer-aided design (CAD) model [163-169].

Components manufactured through SLM exhibit excellent mechanical properties and a strong anisotropy. The directional heat flow during the process leads to columnar grain growth with consequent crystalline texture, which especially affects creep resistance and fatigue life [170-174]. The (001) crystallographic direction has the lowest stiffness involving better creep resistance and longer fatigue lives, thus it is optimal for the upward direction in gas turbine blades.

Recent experiments by Popovich et al. [174] on Inconel 718 demonstrated that suitable SLM process parameters and laser sources allow material anisotropy to be controlled with great design freedom (either single component texture or random oriented grains, or a combination of both of them 
in a specific gradient). The same approach can be also applied to design functional gradients with selected properties and/or heterogeneous composition depending on the specific application.

SEBM is characterized by very high solidification rates and thermal gradients, leading to relevant microstructure refinement with primary dendrite arm spacings two orders of magnitude smaller than as-cast single crystals. Moreover, in samples of the CMSX-4 superalloy prepared with high cooling rates, Parsa et al. [175] observed a high dislocation density, indicating the presence of internal stresses which could lead to crack formation.

\subsection{Welding of Superalloys}

Cracks may form in Ni-based superalloys during both the production process and service life under severe conditions of high temperature and stress in an extremely aggressive environment. Such defects are generally repaired through welding [176], with significant economic saving.

Welding should preserve, as far as possible, the original microstructure without relevant residual stresses in the molten (MZ) and heat affected (HAZ) zones, and chemical segregation changing the composition of $\gamma$ and $\gamma^{\prime}$ phases. During the solidification the microstructure, the MZ is affected by dendritic growth and solute partitioning, with the consequent formation of metallic compounds such as carbides, borides etc. Another critical aspect is connected to the presence of low melting compounds which could lead to micro-cracks after post-welding heat treatments (PWHTs) [177] and local residual stresses in the MZ $[178,179]$.

Some welding technologies are already mature, such as Transient Liquid Phase (TLP) bonding, developed by Pratt \& Whitney Aircraft and based on the spread with Ni-Cr-B or Ni-Cr-B-Si fillers; Activated Diffusion Bonding (ADB) developed by General Electric with fillers of composition close to that of the reference superalloy and with the addition of $\mathrm{B}$ and/or $\mathrm{B}+\mathrm{Si}$; Brazing Diffusion Re-metalling (BDR) developed by SNEMECA with fillers with two components: one of a composition close to that of the alloy, and the other, in small quantities, containing elements such as B and Si which lower the melting point. The advantage of BDR is the slow isothermal solidification that makes the interdiffusion of the elements easier, and guarantees a composition of the joint similar to that of the bulk superalloy. Unfortunately, the costs of the above techniques are very high, particularly BDR.

In recent years, research has been focused on high energy density welding techniques such as Laser Welding (LW) [180-182] and Electron Beam Welding (EBW) [183-186], which provide greater penetration depth, reduced HAZ and minimal distortion, if carried out with a high speed of passes. These techniques seem to be promising, as they represent simpler and cheaper solutions for repairing cracks in Ni-based superalloys. Thanks to a reduced thermal input, high energy density welding techniques, can realize joints with narrower seams and HAZ. By using LW and EBW techniques, the superalloy microstructure is changed at little extent, so that residual stresses, micro-cracks, porosity and other defects in the junction are limited. In addition, for each welded superalloy, the optimization of the process parameters, such as pass speed and pre-heating of the workpiece, clearly plays a crucial role (e.g., see ref. [186-188]).

\section{Conclusions}

The work provides an overview of recent advances in alloys for aeronautic applications, describing current problems and perspectives.

The needs of the aeronautic industry stem from the strong competition to manufacture aircrafts with improved technical features and reduced costs (i.e., extended service life, better fuel efficiency, increased payload). In this challenge, materials play a crucial role. Advanced structural materials should guarantee reduced weight, improved fatigue and wear behaviour, damage tolerance and corrosion resistance, while for the hot engine sections alloys with better creep resistance, mechanical properties at high temperature and high-temperature corrosion resistance are required. 
A critical analysis has been carried out on different kinds of materials including Al alloys, Ti alloys, $\mathrm{Mg}$ alloys, steels, $\mathrm{Ni}$ superalloys and metal matrix composites (MMC), emphasizing the structure-property relationships.

The development of new materials involves new technologies, and some of great relevance for the aeronautic sector have been briefly examined. The attention has been focused on Refill Friction Stir Spot Welding (RFSSW) for joining structural parts made of Al alloys, high energy density techniques for welding Ni superalloys, and Additive Manufacturing (AM) for fabricating components of complex geometry.

In the future, the microstructural and mechanical stability of $\mathrm{Ni}$ superalloys will be further investigated and improved through careful tailoring of the composition to get higher operative temperatures of aero-engines. Important advancements in structural materials are also expected. The competition with Carbon Fiber Reinforced Polymers (CFRP) will drive new efforts to improve the mechanical properties, especially fatigue strength and toughness, and corrosion resistance of $\mathrm{Al}$ alloys. In the case of Ti alloys, the focus will be on the high-temperature resistance to pursue through the control of phases and thermo-mechanical processing. The availability of new types of reinforcing particles and fibers will be exploited to enhance the properties of MMC. Finally, the development of strengthening methods for producing very strong $\mathrm{Mg}$ alloys opens new horizons for the aeronautic applications of these materials which are excellent for weight reduction.

Author Contributions: All the authors contributed to examining the literature and writing the manuscript.

Funding: This research received no external funding.

Conflicts of Interest: The authors declare no conflict of interest.

\section{References}

1. Campbell, F.C. Manufacturing Technology for Aerospace Structural Materials; Elsevier: Amsterdam, The Netherlands, 2006.

2. Zhang, X.; Chen, Y.; Hu, J. Recent advances in the development of aerospace materials. Prog. Aerosp. Sci. 2018, 97, 22-34. [CrossRef]

3. Dursun, T.; Soutis, C. Recent developments in advanced aircraft aluminium alloys. Mater. Des. 2014, 56, 862-871. [CrossRef]

4. Warren, A.S. Developments and challenges for aluminium-A Boeing perspective. Mater. Forum 2004, 28, 24-31.

5. Huda, Z.; Edi, P. Materials selection in design of structures and engines of supersonic aircrafts: A review. Mater. Des. 2013, 46, 552-560. [CrossRef]

6. Banerjee, S.; Robi, P.S.; Srinivasan, A.; Lakavath, P.K. Effect of trace additions of Sn on microstructure and mechanical properties of Al-Cu-Mg alloys. Mater. Des. 2010, 31, 4007-4015. [CrossRef]

7. Yu, J.; Li, X. Modelling of the precipitated phases and properties of Al-Zn-Mg-Cu alloys. J. Phase Equilib. Diffus. 2011, 32, 350. [CrossRef]

8. Schijve, J. Fatigue of Structures and Materials; Kluwer Academic Publishers: Dordrecht, The Netherlands, 2001.

9. Dowling, N.E. Mechanical Behavior of Materials, 3rd ed.; Pearson Prentice Hall: Upper Saddle River, NJ, USA, 2007.

10. 3rd Annual Fatigue Summit; US Navy: Northern Virginia, VA, USA, 2014.

11. Stanzl-Tschegg, S.E.; Meischel, M.; Arcari, A.; Iyyer, N.; Apetre, N.; Phan, N. Combined cycle fatigue of 7075 aluminum alloy-Fracture surface characterization and short crack propagation. Int. J. Fatigue 2016, 91, 352-362. [CrossRef]

12. Merati, A.; Eastaugh, G. Determination of fatigue related discontinuity state of 7000 series of aerospace aluminum alloys. Eng. Fail. Anal. 2007, 14, 673-685. [CrossRef]

13. Cirik, E.; Genel, K. Effect of anodic oxidation on fatigue performance of 7075-T6 alloy. Surf. Coat. Technol. 2008, 202, 5190-5201. [CrossRef]

14. Angella, G.; Di Schino, A.; Donnini, R.; Richetta, M.; Testani, C.; Varone, A. AA7050 Al alloy hot-forging process for improved fracture toughness properties. Metals 2019, 9, 64. [CrossRef] 
15. El-Aty, A.A.; Xu, Y.; Guo, X.; Zhang, S.H.; Ma, Y.; Chen, D. Strengthening mechanisms, deformation behavior, and anisotropic mechanical properties of Al-Li alloys: A review. J. Adv. Res. 2018, 10, 49-67. [CrossRef] [PubMed]

16. Noble, B.; Thompson, G.E. Precipitation characteristics of aluminium-lithium alloys. Met. Sci. J. 1971, 5, 114-120. [CrossRef]

17. Noble, B.; Thompson, G.E. T1(Al2CuLi) precipitation in aluminium-copper-lithium alloys. Met. Sci. J. 1972, 6, 167-174. [CrossRef]

18. Rinker, J.G.; Marek, M.; Sanders, T.H., Jr. Microstructure toughness and stress corrosion cracking behavior of aluminum alloy 2020. Mater. Sci. Eng. 1984, 64, 203-221. [CrossRef]

19. Rioja, R.; Liu, J. The evolution of Al-Li base products for aerospace and space applications. Metall. Mater. Trans. A 2012, 43, 3325-3337. [CrossRef]

20. Wanhill, R.J.H. Aerospace applications of aluminum-lithium alloys. In Aluminum-Lithium Alloys; Elsevier Inc.: Amsterdam, The Netherlands, 2014.

21. Singh, A.; Gokhale, A.A.; Saha, G.G.; Ray, R.K. Texture evolution and anisotropy in Al-Li-Cu-Mg alloys. Textures Mater. Res. 1999, 219-234.

22. Giummarra, C.; Thomas, B.; Rioja, R.J. New aluminium lithium alloys for aerospace applications. In Proceedings of the Light Metals Technology Conference 2007, Saint-Saveur, QC, Canada, 24-26 September 2007; pp. 41-46.

23. Warner, T. Recently developed aluminium solutions for aerospace applications. Mater. Sci. Forum 2006, 519-521, 1271-1278. [CrossRef]

24. Tsivoulas, D.; Prangnell, P. The effect of $\mathrm{Mn}$ and $\mathrm{Zr}$ dispersoid-forming additions on recrystallization resistance in Al-Cu-Li AA2198 sheet. Acta Mater. 2014, 77, 1-16. [CrossRef]

25. Gable, B.M.; Zhu, A.W.; Csontos, A.A.; Starke, E.A., Jr. The role of plastic deformation on the competitive microstructural evolution and mechanical properties of a novel Al-Li-Cu alloy. J. Light Met. 2001, 1, 1-14. [CrossRef]

26. Decreus, B.; Deschamps, A.; De Geuser, F.; Donnadieu, P.; Sigli, C.; Weyland, M. The influence of Cu/Li ratio on precipitation in Al-Cu-Li-x alloys. Acta Mater. 2013, 61, 2207-2218. [CrossRef]

27. Deschamps, A.; Decreus, B.; De Geuser, F.; Dorin, T.; Weyland, M. The influence of precipitation on plastic deformation of Al-Cu-Li-X alloys. Acta Mater. 2013, 61, 4010-4021. [CrossRef]

28. Dorin, T.; De Geuser, F.; Lefebvre, W.; Sigli, C.; Deschamps, A. Strengthening mechanisms of T1 precipitates and their influence on the plasticity of an Al-Cu-Li alloy. Mater. Sci. Eng. A 2014, 605, 119-126. [CrossRef]

29. Dorin, T.; Deschamps, A.; De Geuser, F.; Sigli, C. Quantification and modelling of the microstructure/strength relationship by tailoring the morphological parameters of the T1 phase in an Al-Cu-Li alloy. Acta Mater. 2014, 75, 134-146. [CrossRef]

30. Rodgers, B.I.; Prangnell, P.B. Quantification of the influence of increased pre-stretching on microstructure-strength relationships in the Al-Cu-Li alloy AA2195. Acta Mater. 2016, 108, 55-67. [CrossRef]

31. Lin, Y.; Zheng, Z.; Li, S.; Kong, X.; Han, Y. Microstructures and properties of 2099 Al-Li alloy. Mater. Charact. 2013, 84, 88-99. [CrossRef]

32. Zhang, S.; Zeng, W.; Yang, W.; Shi, C.; Wang, H. Ageing response of a Al-Cu-Li 2198 alloy. Mater. Des. 2014, 63, 368-374. [CrossRef]

33. Kang, S.J.; Kim, T.-H.; Yang, C.-W.; Lee, J.I.; Park, E.S.; Noh, T.W.; Kim, M. Atomic structure and growth mechanism of T1 precipitate in Al-Cu-Li-Mg-Ag alloy. Scr. Mater. 2015, 109, 68-71. [CrossRef]

34. Li, H.Y.; Kang, W.; Lu, X.C. Effect of age-forming on microstructure, mechanical and corrosion properties of a novel Al-Li alloy. J. Alloys Compd. 2015, 640, 210-218. [CrossRef]

35. Fan, X.; He, Z.; Lin, P.; Yuan, S. Microstructure, texture and hardness of Al-Cu-Li alloy sheet during hot gas forming with integrated heat treatment. Mater. Des. 2016, 94, 449-456. [CrossRef]

36. Deschamps, A.; Garcia, M.; Chevy, J.; Davo, B.; De Geuser, F. Influence of Mg and Li content on the microstructure evolution of Al-Cu-Li alloys during long-term ageing. Acta Mater. 2017, 122, 32-46. [CrossRef]

37. Djaaboube, H.; Thabet-Khireddine, D. TEM diffraction study of Al2CuMg (S'/S) precipitation in an Al-Li-Cu-Mg(Zr) alloy. Philos. Mag. 2012, 92, 1876-1889. [CrossRef]

38. Araullo-Peters, V.; Gault, B.; de Geuser, F.; Deschamps, A.; Cairney, J.M. Microstructural evolution during ageing of Al-Cu-Li-X alloys. Acta Mater. 2014, 66, 199-208. [CrossRef] 
39. Rao, K.T.V.; Ritchie, R.O. Fracture toughness behavior of 2090-T83 aluminum-lithium alloy sheet at ambient and cryogenic temperatures. Scr. Metall. 1989, 23, 1129-1134. [CrossRef]

40. Rao, K.T.V.; Ritchie, R.O. Fatigue crack-propagation and cryogenic fracture-toughness behavior in powder-metallurgy aluminum-lithium alloys. Metall. Trans. A 1991, 22, 191-202.

41. Xu, Y.B.; Wang, L.; Zhang, Y.; Wang, Z.G.; Hu, Q.Z. Fatigue and fracture-behavior of an aluminum-lithium Alloy-8090-T6 at ambient and cryogenic temperature. Metall. Trans. A 1991, 22, 723-729. [CrossRef]

42. Sohn, K.S.; Lee, S.; Kim, N.J. In situ observation of microfracture processes in an 8090 Al-Li alloy plate. Mater. Sci. Eng. A 1993, 163, 11-21. [CrossRef]

43. Csontos, A.A.; Starke, E.A. The effect of processing and microstructure development on the slip and fracture behavior of the 2.1 wt. pct. Li AF/C489 and 1.8 wt. pct. Li AF/C458 Al-Li-Cu-X alloys. Metall. Mater. Trans. A 2000, 31, 1965-1976. [CrossRef]

44. Kalyanam, S.; Beaudoin, A.J.; Dodds, R.H., Jr.; Barlat, F. Delamination cracking in advanced aluminum-lithium alloys-Experimental and computational studies. Eng. Fract. Mech. 2009, 76, 2174-2191. [CrossRef]

45. Rawal, S. Metal-matrix composites for space applications. JOM 2001, 53, 14-17. [CrossRef]

46. Kainer, K.U. Metal Matrix Composites; Wiley-Vch: Weinheim, Germany, 2006.

47. Advances in Metal Matrix Composites; Ceschini, L.; Montanari, R. (Eds.) Trans Tech Publications: Zurich, Switzerland, 2011.

48. Tjong, S.C. Recent progress in the development and properties of novel metal matrix nanocomposites reinforced with carbon nanotubes and grapheme nanosheets. Mater. Sci. Eng. R. Rep. 2013, 74, 281-350. [CrossRef]

49. Liao, J.; Tan, M.J.; Sridhar, I. Spark plasma sintered multi-wall carbon nanotube reinforced aluminum matrix composites. Mater. Des. 2010, 31, S96-S100. [CrossRef]

50. Sun, Y.; Zhang, C.; Liu, B.; Meng, Q.; Ma, S.; Dai, W. Reduced graphene oxide reinforced $7075 \mathrm{Al}$ matrix composites: Powder synthesis and mechanical properties. Metals 2017, 7, 499. [CrossRef]

51. Shimizu, Y.; Nishimura, T.; Matsushima, I. Corrosion resistance of Al-based metal matrix composites. Mater. Sci. Eng. A 1995, 198, 113-118. [CrossRef]

52. Chen, C.; Mansfeld, F. Corrosion protection of an Al 6092/SiCP metal matrix composite. Corros. Sci. 1996, 39, 1075-1082. [CrossRef]

53. Fang, C.K.; Huang, C.C.; Chuang, T.H. Synergistic effects of wear and corrosion for $\mathrm{Al}_{2} \mathrm{O}_{3}$ particulate-reinforced 6061 aluminum matrix composites. Metall. Mater. Trans. A 1999, 30, 643-651. [CrossRef]

54. Hihara, L.H.; Latanision, R.M. Galvanic corrosion of aluminum-matrix composites. Corrosion 1992, 48, 546-552. [CrossRef]

55. Pardo, A.; Merino, M.C.; Merino, S.; Viejo, F.; Carboneras, M.; Arrabal, R. Influence of reinforcement proportion and matrix composition on pitting corrosion behaviour of cast aluminium matrix composites (A3xx.x/SiCp). Corros. Sci. 2005, 47, 1750-1764. [CrossRef]

56. Veeresh Kumar, G.M.; Rao, C.S.P.; Selvaraj, N.; Bhagyashekar, M.S. Studies on Al6061-SiC and Al7075-Al2O3 Metal Matrix Composites. J. Miner. Mater. Charact. Eng. 2010, 9, 43-55.

57. Candan, S. An investigation on corrosion behaviour of pressure infiltrated Al-Mg alloy/SiCp composites. Corros. Sci. 2009, 51, 1392-1398. [CrossRef]

58. Patil, C.; Patil, H.; Patil, H. Experimental investigation of hardness of FSW and TIG joints of Aluminium alloys of AA7075 and AA6061. Fract. Struct. Integr. 2016, 37, 325-332. [CrossRef]

59. Hancock, R. Friction welding of aluminum cuts energy cost by 99\%. Weld. J. 2004, 83, 40-45.

60. Kenichiro, M.; Niels, B.; Livan, F.; Micari, F.; Tekkaya, A.E. Joining by plastic deformation. CIRP Ann. 2013, 62, 673-694.

61. Aota, K.; Takahashi, M.; Ikeuchi, K. Friction stir spot welding of aluminum to steel by rotating tool without probe. Weld. Int. 2010, 24, 96-104. [CrossRef]

62. Uematsu, Y.; Tokaji, K. Comparison of fatigue behaviour between resistance spot and friction stir spot welded aluminium alloy sheets. Sci. Technol. Weld. Join. 2009, 14, 62-71. [CrossRef]

63. Zhang, Z.; Yang, X.; Zhang, J.; Zhou, G.; Xu, X.; Zou, B. Effect of welding parameters on microstructure and mechanical properties of friction stir spot welded 5052 aluminum alloy. Mater. Des. 2011, 32, 4461-4470. [CrossRef] 
64. Tutar, M.; Aydin, H.; Yuce, C.; Yavuz, N.; Bayram, A. The optimisation of process parameters for friction stir spot-welded AA3003-H12 aluminium alloy using a Taguchi orthogonal array. Mater. Des. 2014, 63, 789-797. [CrossRef]

65. Tier, M.D.; Rosendo, T.S.; dos Santos, J.F.; Huber, N.; Mazzaferro, J.A.; Mazzaferro, C.P.; Strohaecker, T.R. The influence of refill FSSW parameters on the microstructure and shear strength of 5042 aluminium welds. J. Mater. Process. Technol. 2013, 213, 997-1005. [CrossRef]

66. Yang, H.G.; Yang, H.J. Experimental investigation on refill friction stir spot welding process of aluminum alloys. Appl. Mech. Mater. 2013, 345, 243-246. [CrossRef]

67. Lacki, P.; Derlatka, A. Experimental and numerical investigation of aluminium lap joints made by RFSSW. Meccanica 2016, 51, 455-462. [CrossRef]

68. Kluz, R.; Kubit, A.; Wydrzyński, D. The effect of plunge depth on the strength properties of friction welded joints using the RFSSW method. Adv. Sci. Tech. Res. J. 2018, 12, 41-47. [CrossRef]

69. Kluz, R.; Kubit, A.; Wydrzyński, D. The effect of RFSSW parameters on the load bearing capacity of aluminum 7075-T6 sheet metal joints. Adv. Sci. Tech. Res. J. 2018, 12, 35-41. [CrossRef]

70. Yang, H.G.; Yang, H.J.; Hu, X. Simulation on the plunge stage in refill friction stir spot welding of Aluminum Alloys. In Proceedings of the 4th International Conference on Mechatronics, Materials, Chemistry and Computer Engineering, Xi'an, China, 12-13 December 2015; pp. 521-524.

71. Simbi, D.J.; Schully, J.C. The effect of residual interstitial elements and iron on mechanical properties of commercially pure titanium. Mater. Lett. 1996, 26, 35-39. [CrossRef]

72. Ouchi, C.; Iizumi, H.; Mitao, S. Effects of ultra-high purification and addition of interstitial elements on properties of pure titanium and titanium alloys. Mater. Sci. Eng. A 1998, 243, 186-195. [CrossRef]

73. Malinov, S.; Sha, W.; Guo, Z.; Tang, C.C.; Long, A.E. Synchrotron X-ray diffraction study of the phase transformations in titanium alloys. Mater. Charact. 2002, 48, 279-295. [CrossRef]

74. Choo, H.; Rangaswamy, P.; Bourke, M.A.M.; Larsen, J.M. Thermal expansion anisotropy in a Ti-6Al-4V/SiC composite. Mater. Sci. Eng. A 2002, 325, 236-241. [CrossRef]

75. Pederson, R.; Babushkin, O.; Skystedt, F.; Warren, R. Use of high temperature X-ray diffractometry to study phase transitions and thermal expansion properties in Ti-6Al-4V. Mater. Sci. Technol. 2003, 19, 1533-1538. [CrossRef]

76. Montanari, R.; Costanza, G.; Tata, M.E.; Testani, C. Lattice expansion of Ti-6Al-4V by nitrogen and oxygen absorption. Mater. Charact. 2008, 59, 334. [CrossRef]

77. Che Haron, C.H.; Jawaid, A. The effect of machining on surface integrity of titanium alloy Ti-6\%Al-4\%V. J. Mater. Process. Technol. 2005, 166, 188-192. [CrossRef]

78. Axinte, D.A.; Kritmanorot, M.; Axinte, M.; Gindy, N.N.Z. Investigations on belt polishing of heat-resistant titanium alloy. J. Mater. Process. Technol. 2005, 166, 398-404. [CrossRef]

79. Ginting, A.; Nouari, M. Surface integrity of dry machined titanium alloys. Int. J. Mach. Tools Manuf. 2009, 49, 325-332. [CrossRef]

80. Patil, S.; Jadhav, S.; Kekade, S.; Supare, A.; Powar, A.; Singh, R.K.P. The Influence of Cutting Heat on the Surface Integrity during Machining of Titanium Alloy Ti6Al4V. Procedia Manuf. 2016, 5, 857-869. [CrossRef]

81. Veiga, C.; Davim, J.; Loureiro, A. Properties and applications of titanium alloys: A brief review. Rev. Adv. Mater. Sci. 2012, 32, 133-148.

82. Jiang, X.J.; Jing, R.; Liu, C.Y.; Ma, M.Z.; Liu, R.P. Structure and mechanical properties of TiZr binary alloy after Al addition. Mater. Sci. Eng. A 2013, 586, 301-305. [CrossRef]

83. Boyer, R.; Briggs, R. The use of beta titanium alloys in the aerospace industry. J. Mater. Eng. Perform. 2013, 22, 2916-2920.

84. Cotton, J.D.; Briggs, R.D.; Boyer, R.R.; Tamirisakandala, S.; Russo, P.; Shchetnikov, N.; Fanning, J.C. State of the art in beta titanium alloys for airframe applications. JOM 2015, 67, 1281-1303. [CrossRef]

85. Lu, J.; Zhao, Y.; Ge, P.; Zhang, Y.; Niu, H.; Zhang, W.; Zhang, P. Precipitation behavior and tensile properties of new high strength beta titanium alloy Ti-1300. J. Alloys Comp. 2015, 637, 1-4. [CrossRef]

86. Wood, J.R.; Russo, P.A.; Welter, M.F.; Crist, E.M. Thermomechanical processing and heat treatment of Ti-6Al-2Sn-2Zr-2Cr-2Mo-Si for structural application. Mater. Sci. Eng. A 1998, 243, 109-118. [CrossRef]

87. Cui, C.; Hu, B.M.; Zhao, L.; Liu, S. Titanium alloy production technology, market prospects and industry development. Mater. Des. 2011, 32, 1684-1691. [CrossRef] 
88. Jing, R.; Liang, S.X.; Liu, C.Y.; Ma, M.Z.; Zhang, X.Y.; Liu, R.P. Structure and mechanical properties of Ti-6Al-4V alloy after zirconium additio. Mater. Sci. Eng. A 2012, 552, 295-300. [CrossRef]

89. Nourbakhsh, S.; Margolin, H. Fabrication of high temperature fiber reinforced intermetallic matrix composites. In Proceedings of the International Conference of Metal and Ceramic Matrix Composites: Processing, Modeling and Mechanical Behaviour, Anaheim, CA, USA, 19-22 February 1990; pp. 75-90.

90. Mittnick, M.A. Continuous SiC Fibers Reinforced Metals. In Proceedings of the TMS Annual Meeting, Anaheim, CA, USA, 18-22 February 1990; p. 605.

91. Upadhyaya, D.; Brydson, R.; Tsakiropoulos, P.; Ward-Close, C.M. A Comparison of SCS-6/Ti-6Al-4V and sigma SM1240/Ti-6Al-4V composite system: A microstructural characterization. In Recent Advances in Titanium Metal Matrix Composites; Froes, F.H., Storer, J., Eds.; TMS: Warrendale, PA, USA, 1994; pp. 139-154.

92. Clyne, T.W. Metal matrix composites: Matrices and processing. In Encyclopaedia of Materials: Science and Technology, Composites: MMC, CMC, PMC; Mortensen, A., Ed.; Elsevier: Amsterdam, The Netherlands, 2001.

93. Tata, M.E.; Montanari, R.; Testani, C.; Valdrè, G. Preparazione del composito Ti6Al4V+SiC fibre e sua evoluzione strutturale dopo trattamenti termici. Metall. Ital. 2005, 7-8, 43-50.

94. Mezzi, A.; Donnini, R.; Kaciulis, S.; Montanari, R.; Testani, C. Composite of Ti6Al4V and SiC fibres: Evolution of fibre-matrix interface during heat treatments. Surf. Interface Anal. 2008, 40, 277-280.

95. Donnini, R.; Kaciulis, S.; Mezzi, A.; Montanari, R.; Testani, C. Production and heat treatments of Ti6Al4V-SiC composite. Part I- Microstructural characterization. Mater. Sci. Forum 2009, 604-605, 331-340.

96. Deodati, P.; Donnini, R.; Montanari, R.; Testani, C.; Valente, T. Production and heat treatments of Ti6Al4V-SiC $f$ composite. Part II- Mechanical characterization. Mater. Sci. Forum 2009, 604-605, 341-350.

97. Deodati, P.; Donnini, R.; Montanari, R.; Testani, C. High temperature damping behaviour of Ti6Al4V+SiC composite. Mater. Sci. Eng. A 2009, 521-522, 318-321. [CrossRef]

98. Amadori, S.; Bonetti, E.; Deodati, P.; Donnini, R.; Montanari, R.; Pasquini, L.; Testani, C. Low temperature damping behaviour of Ti6Al4V+SiC $\mathrm{f}_{\mathrm{f}}$ composite. Mater. Sci. Eng. A 2009, 521-522, 340-342. [CrossRef]

99. Deodati, P.; Donnini, R.; Kaciulis, S.; Mezzi, A.; Montanari, R.; Testani, C. Microstructural characterisation of $\mathrm{Ti}_{\mathrm{Al}} \mathrm{V}-\mathrm{SiC}_{\mathrm{f}}$ composite produced by new roll-bonding process. Adv. Mater. Res. 2010, 89-91, 715-720. [CrossRef]

100. Deodati, P.; Donnini, R.; Kaciulis, S.; Mezzi, A.; Montanari, R.; Testani, C.; Ucciardello, N. Anelastic phenomena at the fibre-matrix interface of the Ti6Al4V-SiC $f_{f}$ composite. Key Eng. Mater. 2010, 425, 263-270. [CrossRef]

101. Kaciulis, S.; Mezzi, A.; Donnini, R.; Deodati, P.; Montanari, R.; Ucciardello, N.; Amati, M.; Kazemian-Abyaneh, M.; Testani, C. Micro-chemical charaterization of carbon-metal interface in Ti6Al4V-SiC $\mathrm{f}_{\mathrm{f}}$ composites. Surf. Interface Anal. 2010, 42, 707-711. [CrossRef]

102. Testani, C.; Ferraro, F.; Deodati, P.; Donnini, R.; Montanari, R.; Kaciulis, S.; Mezzi, A. Comparison between roll diffusion bonding and hot isostatic pressing production processes of $\mathrm{Ti}_{6} \mathrm{Al} 14 \mathrm{~V}-\mathrm{SiC}_{\mathrm{f}}$ metal matrix composites. Mater. Sci. Forum 2011, 678, 145-154. [CrossRef]

103. Silvan, J.F.; Bihr, J.C.; Lepetitcorps, Y. EPMA and XPS studies of TiAlSiC interfacial chemical compatibility. Compos. Part A 1996, 27, 691-695. [CrossRef]

104. Fu, Y.C.; Shi, N.L.; Zhang, D.Z.; Yang, R. Effect of C coating on the interfacial microstructure and properties of SiC fiber-reinforced Ti matrix composites. Mater. Sci. Eng. A 2006, 426, 278-282. [CrossRef]

105. Van Vlack, L.H. Elements of Materials Science and Engineering, 5th ed.; Addison-Wesley: Boston, MA, USA, 1985.

106. Swart, H.C.; Jonker, A.J.; Claassens, C.H.; Chen, R.; Venter, L.A.; Ramoshebe, P.; Wurth, E.; Terblans, J.J.; Roos, W.D. Extracting inter-diffusion parameters of TiC from AES depth profiles. Appl. Surf. Sci. 2003, 205, 231-239. [CrossRef]

107. Luo, A.A. Magnesium casting technology for structural applications. J. Magn. Alloys 2013, 1, 2-22. [CrossRef]

108. Luo, A.A.; Sadayappan, K. Technology for Magnesium Castings; American Foundry Society: Schaumburg, IL, USA, 2011; pp. 29-47.

109. Bettles, C.; Gibson, M. Current wrought magnesium alloys: Strengths and weaknesses. JOM 2005, 57, 46-49. [CrossRef]

110. Ostrovsky, I.; Henn, Y. Present state and future of magnesium application in aerospace industry. In Proceedings of the International Conference New Challenges in Aeronautics, ASTEC'07, Moscow, Russia, 19-22 August 2007.

111. Mordike, B.L.; Ebert, T. Magnesium-properties-applications-potential. Mater. Sci. Eng. A 2001, 302, 37-45. [CrossRef] 
112. Pekguleryuz, M.; Labelle, P.; Argo, D. Magnesium die casting alloy AJ62x with superior creep resistance, ductility and die castability. J. Mater. Manuf. 2003, 112, 24-29.

113. Yamashita, A.; Horita, Z.; Langdon, T.G. Improving the mechanical properties of magnesium and a magnesium alloy through severe plastic deformation. Mater. Sci. Eng. A 2001, 300, 142-147. [CrossRef]

114. Jian, W.W.; Kang, Z.X.; Li, Y.Y. Effect of hot plastic deformation on microstructure and mechanical property of Mg-Mn-Ce magnesium alloy. Trans. Nonferr. Met. Soc. China 2007, 17, 1158-1163. [CrossRef]

115. Ma, A.B.; Jiang, J.H.; Saito, N.; Shigematsu, I.; Yuan, Y.C.; Yang, D.H.; Nishida, Y. Improving both strength and ductility of a Mg alloy through a large number of ECAP passes. Mater. Sci. Eng. A 2009, 513-514, 122-127. [CrossRef]

116. Lian, J.S.; Valiev, R.Z.; Baudelet, B. On the enhanced grain growth in ultrafine grained metals. Acta Metall. Mater. 1995, 43, 4165-4170. [CrossRef]

117. Wu, X.L.; Youssef, K.M.; Koch, C.C.; Mathaudhu, S.N.; Kecskes, L.J.; Zhu, Y.T. Deformation twinning in a nanocrystalline hcp Mg alloy. Scr. Mater. 2011, 64, 213-216. [CrossRef]

118. Zhu, Y.T.; Liao, X.Z.; Wu, X.L. Deformation twinning in nanocrystalline materials. Prog. Mater. Sci. 2012, 57, 1-62. [CrossRef]

119. Lu, K.; Lu, L.; Suresh, S. Strengthening materials by engineering coherent internal boundaries at the nanoscale. Science 2009, 324, 349-352. [CrossRef] [PubMed]

120. Chen, Y.; Xu, Z.; Smith, C.; Sankar, J. Recent advances on the development of magnesium alloys for biodegradable implants. Acta Biomater. 2014, 10, 4561-4573. [CrossRef] [PubMed]

121. Wen, Z.; Wu, C.; Dai, C.; Yang, F. Corrosion behaviors of $\mathrm{Mg}$ and its alloys with different $\mathrm{Al}$ contents in a modified simulated body fluid. J. Alloys Compd. 2009, 488, 392-399. [CrossRef]

122. Zhang, B.; Geng, L.; Wang, Y. Research on Mg-Zn-Ca Alloy as Degradable Biomaterial. In Biomaterials Physics and Chemistry; Pignatello, R., Ed.; INTECH Open Access Publisher: Rijeka, Croatia, 2011; pp. 183-204.

123. Song, Y.; Han, E.-H.; Shan, D.; Yim, C.D.; You, B.S. The effect of Zn concentration on the corrosion behavior of Mg-xZn alloys. Corros. Sci. 2012, 65, 322-330. [CrossRef]

124. Homma, T.; Mendis, C.L.; Hono, K.; Kamado, S. Effect of Zr addition on the mechanical properties of as-extruded Mg-Zn-Ca-Zr alloys. Mater. Sci. Eng. A 2010, 527, 2356-2362. [CrossRef]

125. Xu, D.K.; Tang, W.N.; Liu, L.; Xu, Y.B.; Han, E.H. Effect of $Y$ concentration on the microstructure and mechanical properties of as-cast Mg-Zn-Y-Zr alloys. J. Alloys Compd. 2007, 432, 129-134. [CrossRef]

126. Jian, W.W.; Cheng, G.M.; Xu, W.Z.; Yuan, H.; Tsai, M.H.; Wang, Q.D.; Koch, C.C.; Zhu, Y.T.; Mathaudhu, S.N. Ultrastrong Mg alloy via nano-spaced stacking faults. Mater. Res. Lett. 2013, 1, 61-66. [CrossRef]

127. Inoue, A.; Kawamura, Y.; Matsushita, M.; Hayashi, K.; Koike, J. Novel hexagonal structure and ultrahigh strength of magnesium solid solution in the Mg-Zn-Y system. J. Mater. Res. 2001, 16, 1894-1900. [CrossRef]

128. Cwiek, J. Prevention methods against hydrogen degradation of steel. J. Achiev. Mater. Manuf. Eng. 2010, 43, 214-221.

129. Ukai, S.; Fujiwara, M. Perspective of ODS alloys application in nuclear environments. J. Nucl. Mater. 2002, 307-311, 749-757. [CrossRef]

130. Klueh, R.L.; Gelles, D.S.; Jitsukawa, S.; Kimura, A.; Odette, G.R.; van der Schaaf, B.; Victoria, M. Ferritic/martensitic steels - overview of recent results. J. Nucl. Mater. 2002, 307-311, 455-465. [CrossRef]

131. De Castro, V.; Leguey, T.; Muñoz, A.; Monge, M.A.; Fernández, P.; Lancha, A.M.; Pareja, R. Mechanical and microstructural behavior of $\mathrm{Y}_{2} \mathrm{O}_{3}$ ODS EUROFER 97. J. Nucl. Mater. 2007, 367-370, 196-201. [CrossRef]

132. De Castro, V.; Leguey, T.; Auger, M.A.; Lozano-Perez, S.; Jenkins, M.L. Analytical characterization of secondary phases and void distributions in an ultrafine-grained ODS Fe-14Cr model alloy. J. Nucl. Mater. 2011, 417, 217-220. [CrossRef]

133. De Carlan, Y.; Bechade, J.L.; Dubuisson, P.; Seran, J.L.; Billot, P.; Bougault, A.; Cozzika, T.; Doriot, S.; Hamon, D.; Henry, J.; et al. CEA developments of new ferritic ODS alloys for nuclear applications. J. Nucl. Mater. 2009, 386-388, 430-432. [CrossRef]

134. Wang, M.; Zhou, Z.; Sun, H.; Hu, H.; Li, S. Microstructural observation and tensile properties of ODS-304 austenitic steel. Mater. Sci. Eng. A 2013, 559, 287-292. [CrossRef]

135. Kasada, R.; Lee, S.G.; Isselin, J.; Lee, J.H.; Omura, T.; Kimura, A.; Okuda, T.; Inoue, M.; Ukai, S.; Ohnuki, S.; et al. Anisotropy in tensile and ductile-brittle transition behavior of ODS ferritic steels. J. Nucl. Mater. 2011, 417, 180-184. [CrossRef] 
136. Kawahara, M.; Kim, H.; Tokita, M. Fabrication of nano-materials by the spark plasma sintering (SPS) method. In Proceedings of the Powder Metallurgy World Congress, Kyoto, Japan, 12-16 November 2000; pp. 741-744.

137. Zhang, H.W.; Gopalan, R.; Mukai, T.; Hono, K. Fabrication of bulk nanocrystalline Fe-C alloy by spark plasma sintering of mechanically milled powder. Scr. Mater. 2005, 53, 863-868. [CrossRef]

138. De Sanctis, M.; Fava, A.; Lovicu, G.; Montanari, R.; Richetta, M.; Testani, C.; Varone, A. Mechanical characterization of a nano-ODS steel prepared by low-energy mechanical alloying. Metals 2017, 7, 283. [CrossRef]

139. Fava, A.; Montanari, R.; Richetta, M.; Testani, C.; Varone, A. Analysis of strengthening mechanisms in nano-ODS steel depending on preparation route. J. Mater. Sci. Eng. 2018, 7, 1-10. [CrossRef]

140. Serrano, M.; Hernández-Mayoral, M.; García-Junceda, A. Microstructural anisotropy effect on the mechanical properties of a 14Cr ODS steel. J. Nucl. Mater. 2012, 428, 103-109. [CrossRef]

141. Deodati, P.; Montanari, R.; Tassa, O.; Ucciardello, N. Single crystal PWA 1483 superalloy: Dislocation rearrangement and damping phenomena. Mater. Sci. Eng. A 2009, 521-522, 102-105. [CrossRef]

142. Costanza, G.; Montanari, R.; Richetta, M.; Tata, M.E.; Varone, A. Evaluation of structural stability of materials through Mechanical Spectroscopy. Four case studies. Metals 2016, 6, 306. [CrossRef]

143. Montanari, R.; Tassa, O.; Varone, A. Early instability phenomena of IN792 DS superalloy. Mater. Sci. Forum 2017, 879, 2026-2031. [CrossRef]

144. Pollock, T.M.; Argon, A.S. Creep resistance of CMSX-3 nickel base superalloy single crystals. Acta Metall. Mater. 1992, 40, 1. [CrossRef]

145. Yeh, A.C.; Tin, S. Effects of Ru and Re additions on high temperature flow stresses of nickel-base single crystal superalloys. Scr. Mater. 2005, 52, 519-526. [CrossRef]

146. Wang, W.-Z.; Jin, T.; Sun, X.-F.; Guan, H.-R.; Hu, Z.-Q. Role of Re and Co on microstructures and $\gamma^{\prime}$ coarsening in single crystal superalloys. Mater. Sci. Eng. A 2008, 479, 148-158. [CrossRef]

147. Tian, S.-G.; Liang, F.-S.; Li, A.-N.; Li, J.-J.; Qian, B.-J. Microstructure evolution and deformation features of single crystal nickel-based superalloy containing $4.2 \%$ Re during creep. Trans. Nonferrous Met. Soc. China 2011, 21, 1532-1537. [CrossRef]

148. Kaciulis, S.; Mezzi, A.; Amati, M.; Montanari, R.; Angella, G.; Maldini, M. Relation between the Microstructure and Microchemistry in Ni-based Superalloy. Surf. Interf. Anal. 2012, 44, 982-985. [CrossRef]

149. Rae, C.M.F.; Reed, R.C. The precipitation of topologically close-packed phases in rhenium-containing superalloys. Acta Mater. 2001, 49, 4113-4125. [CrossRef]

150. Zhao, X.B.; Liu, L.; Yu, Z.H.; Zhang, W.G.; Fu, H.Z. Microstructure development of different orientated nickel-base single crystal superalloy in directional solidification. Mater. Charact. 2010, 61, 7. [CrossRef]

151. Guan, X.; Liu, E.; Zheng, Z.; Yu, Y.; Tong, J.; Zhai, Y.; Zhai, Y. Solidification behavior and segregation of Re-containing cast Ni-base superalloy with different Cr content. J. Mater. Sci. Technol. 2011, 27, 113-117.

152. Kearsey, R.M.; Beddoes, J.C.; Jones, P.; Au, P. Compositional design considerations for microsegregation in single crystal superalloy systems. Intermetallics 2004, 12, 903-910. [CrossRef]

153. Zheng, L.; Gu, C.Q.; Zheng, Y.R. Investigation of the solidification behavior of a new Ru-containing cast Ni-base superalloy with high W content. Scr. Mater. 2004, 50, 435. [CrossRef]

154. Huang, X.; Zhang, Y.; Liu, Y.; Hu, Z. Effect of small amount of nitrogen on carbide characteristics in unidirectional Ni-base superalloy. Metall. Mater. Trans. A 1997, 28, 2143-2147. [CrossRef]

155. Bor, H.Y.; Chao, C.G.; Ma, C.Y. The influence of magnesium on carbide characteristics and creep behavior of the mar-m247 superalloy. Scr. Mater. 1998, 38, 329-335. [CrossRef]

156. Kumar, M.; Schwartz, A.J.; King, W.E. Microstructural evolution during grain boundary engineering of low to medium stacking fault energy fcc materials. Acta Mater. 2002, 50, 2599-2612. [CrossRef]

157. Jin, Y.; Bernacki, M.; Agnoli, A.; Lin, B.; Rohrer, G.S.; Rollett, A.D.; Bozzolo, N. Evolution of the annealing twin density during $\delta$-supersolvus grain growth in the nickel-based superalloy Inconel 718. Metals 2016, 6, 5. [CrossRef]

158. Kuppan, P.; Rajadurai, A.; Narayanan, S. Influence of EDM process parameters in deep hole drilling of Inconel 718. Int. J. Adv. Manuf. Technol. 2008, 38, 74-84. [CrossRef]

159. Imran, M.; Mativenga, P.T.; Kannan, S.; Novovic, D. An experimental investigation of deep-hole microdrilling capability for a nickel-based superalloy. Proc. Inst. Mech. Eng. B J. Eng. Manuf. 2008, 222, 1589-1596. [CrossRef] 
160. Leigh, S.; Sezer, K.; Li, L.; Grafton-Reed, C.; Cuttell, M. Statistical analysis of recast formation in laser drilled acute blind holes in CMSX-4 nickel superalloy. Int. J. Adv. Manuf. Technol. 2009, 43, 1094-1105. [CrossRef]

161. Okasha, M.M.; Mativenga, P.T.; Driver, N.; Li, L. Sequential laser and mechanical micro-drilling of Ni superalloy for aerospace application. CIRP Ann. 2010, 59, 199-202. [CrossRef]

162. Soo, S.L.; Hood, R.; Aspinwall, D.K.; Voice, W.E.; Sage, C. Machinability and surface integrity of RR1000 nickel based superalloy. CIRP Ann. 2011, 60, 89-92. [CrossRef]

163. Dadbakhsh, S.; Hao, L. Effect of Al alloys on selective laser melting behaviour and microstructure of in situ formed particle reinforced composites. J. Alloys Comp. 2012, 541, 328-334. [CrossRef]

164. Song, B.; Dong, S.J.; Coddet, P.; Zhou, G.S.; Ouyang, S.; Liao, H.L.; Coddet, C. Microstructure and tensile behavior of hybrid nano-micro $\mathrm{SiC}$ reinforced iron matrix composites produced by selective laser melting. J. Alloys Compd. 2013, 579, 415-421. [CrossRef]

165. Zhang, B.C.; Fenineche, N.E.; Liao, H.L.; Coddet, C. Microstructure and magnetic properties of Fe-Ni alloy fabricated by selective laser melting Fe/Ni mixed powders. J. Mater. Sci. Technol. 2013, 29, 757-760. [CrossRef]

166. Zhang, B.C.; Liao, H.L.; Coddet., C. Microstructure evolution and density behavior of CP Ti parts elaborated by Self-developed vacuum selective laser melting system. Appl. Surf. Sci. 2013, 279, 310-316. [CrossRef]

167. Murr, L.E.; Martinez, E.; Gaytan, S.M.; Ramirez, D.A.; Machado, B.I.; Shindo, P.W.; Martinez, J.L.; Medina, F.; Wooten, J.; Ciscel, D.; et al. Microstructural architecture, microstructures and mechanical properties for a Nickel-Base superalloy fabricated by electron beam melting. Metall. Mater. Trans. A 2011, 42, 3491-3508. [CrossRef]

168. Helmer, H.E.; Körner, C.; Singer, R.F. Additive manufacturing of nickel-based superalloy Inconel 718 by selective electron beam melting: Processing window and microstructure. J. Mater. Res. 2014, 29, 1987-1996. [CrossRef]

169. Ramsperger, M.; Singer, R.; Körner, C. Microstructure of the Nickel-Base superalloy CMSX-4 fabricated by selective electron beam melting. Metall. Mater. Trans. A 2016, 47, 1469-1480. [CrossRef]

170. Jia, Q.; Gu, D. Selective laser melting additive manufacturing of Inconel 718 superalloy parts: Densification, microstructure and properties. J. Alloys Comp. 2014, 585, 713-721. [CrossRef]

171. Song, B.; Dong, S.; Coddet, P.; Liao, H.; Coddet, C. Fabrication of NiCr alloy parts by selective laser melting: Columnar microstructure and anisotropic mechanical behaviour. Mater. Des. 2010, 53, 1-7. [CrossRef]

172. Thijs, L.; Sistiaga, M.M.; Wauthlé, R.; Xie, Q.; Kruth, J.; Van Humbeeck, J. Strong morphological and crystallographic texture and resulting yield strength anisotropy in Selective Laser Melted tantalum. Acta Mater. 2013, 61, 4657-4668. [CrossRef]

173. Geiger, F.; Kunze, K.; Etter, T. Tailoring the texture of IN738LC processed by selective laser melting (SLM) by specifc scanning strategies. Mater. Sci. Eng. 2016, 661, 240-246. [CrossRef]

174. Popovich, V.A.; Borisov, E.V.; Popovich, A.A.; Suliarov, V.S.; Masaylo, D.V.; Alzina, L. Functionally graded Inconel 718 processed by additive manufacturing: Crystallographic texture, anisotropy of microstructure and mechanical properties. Mater. Des. 2017, 114, 441-449. [CrossRef]

175. Parsa, A.B.; Ramsperger, M.; Kostka, A.; Somsen, C.; Körner, C.; Eggeler, G. Transmission electron microscopy of a CMSX-4 Ni-base superalloy produced by selective electron beam melting. Metals 2016, 6, 258. [CrossRef]

176. David, S.A.; Vitek, J.M.; Babu, S.S.; Boatner, L.A.; Reed, R.W. Welding of nickel base superalloy single crystals. Sci. Technol. Weld. Join. 1997, 2, 79-88. [CrossRef]

177. Ojo, O.A.; Richards, N.L.; Chaturvedi, M.C. Microstructural study of weld fusion zone of TIG welded IN 738LC nickel-based superalloy. Scr. Mater. 2004, 51, 683. [CrossRef]

178. Henderson, M.B.; Arrell, D.; Heobel, M.; Larsson, R.; Marchanty, G. Nickel-based superalloy welding practices for industrial gas turbine applications. Sci. Technol. Weld. Join. 2013, 9, 13-21. [CrossRef]

179. Jensen, M.V.R.S.; Dye, D.; James, K.E.; Korsunsky, A.M.; Roberts, S.M.; Reed, R.C. Residual stresses in a welded superalloy disc: Characterization using synchrotron diffraction and numerical process modeling. Metall. Trans. A 2002, 33, 2921. [CrossRef]

180. Zapirain, F.; Zubiri, F.; Garciandía, F.; Tolosa, I.; Chueca, S.; Goiria, A. Development of laser welding of $\mathrm{Ni}$ based superalloys for aeronautic engine applications (experimental process and obtained properties). Phys. Procedia 2011, 12, 105-112. [CrossRef]

181. Angella, G.; Barbieri, G.; Donnini, R.; Montanari, R.; Varone, A. Welding of IN792 DS superalloy by high energy density techniques. Mater. Sci. Forum 2017, 884, 166-177. [CrossRef] 
182. Barbieri, G.; Bifaretti, S.; Bonaiuto, V.; Montanari, R.; Richetta, M.; Varone, A. Laser beam welding of IN792 DS superalloy. Mater. Sci. Forum 2018, 941, 1149-1154. [CrossRef]

183. Chen, G.Q.; Zhang, B.; Lu, T.; Feng, J.C. Causes and control of welding cracks in electron-beam-welded superalloy GH4169 joints. Trans. Nonferrous Met. Soc. China 2013, 23, 1971-1976. [CrossRef]

184. Montanari, R.; Varone, A.; Barbieri, G.; Soltani, P.; Mezzi, A.; Kaciulis, S. Welding of IN792 DS superalloy by electron beam. Surf. Interface Anal. 2016, 48, 483-487. [CrossRef]

185. Barbieri, G.; Soltani, P.; Kaciulis, S.; Montanari, R.; Varone, A. IN792 DS superalloy: Optimization of EB welding and post-welding heat treatments. Mater. Sci. Forum 2017, 879, 175-180. [CrossRef]

186. Angella, G.; Barbieri, G.; Donnini, R.; Montanari, R.; Richetta, M.; Varone, A. Electron beam welding of IN792 DS: Effects of pass speed and PWHT on microstructure and hardness. Materials 2017, 10, 1033. [CrossRef]

187. Huang, C.A.; Wang, T.H.; Lee, C.H.; Han, W. A study of the heat-affected zone (HAZ) of an Inconel 718 sheet welded with electron-beam welding (EBW). Mater. Sci. Eng. A 2005, 398, 275-281. [CrossRef]

188. Ferro, P.; Zambon, A.; Bonollo, F. Investigation of electron-beam welding in wrought Inconel 706, experimental and numerical analysis. Mater. Sci. Eng. A 2005, 392, 94-105. [CrossRef]

(C) 2019 by the authors. Licensee MDPI, Basel, Switzerland. This article is an open access article distributed under the terms and conditions of the Creative Commons Attribution (CC BY) license (http://creativecommons.org/licenses/by/4.0/). 